\title{
WestVirginiaUniversity
}

THE RESEARCH REPOSITORY @ WVU

Graduate Theses, Dissertations, and Problem Reports

2000

\section{Evaluation of maternal serum triple screen as an identifier of trisomy 21 pregnancy}

Jonnie Ann Lane

West Virginia University

Follow this and additional works at: https://researchrepository.wvu.edu/etd

\section{Recommended Citation}

Lane, Jonnie Ann, "Evaluation of maternal serum triple screen as an identifier of trisomy 21 pregnancy" (2000). Graduate Theses, Dissertations, and Problem Reports. 1127.

https://researchrepository.wvu.edu/etd/1127

This Thesis is protected by copyright and/or related rights. It has been brought to you by the The Research Repository @ WVU with permission from the rights-holder(s). You are free to use this Thesis in any way that is permitted by the copyright and related rights legislation that applies to your use. For other uses you must obtain permission from the rights-holder(s) directly, unless additional rights are indicated by a Creative Commons license in the record and/ or on the work itself. This Thesis has been accepted for inclusion in WVU Graduate Theses, Dissertations, and Problem Reports collection by an authorized administrator of The Research Repository @ WVU. For more information, please contact researchrepository@mail.wvu.edu. 


\title{
EVALUATION OF MATERNAL SERUM TRIPLE SCREEN AS AN IDENTIFIER OF TRISOMY 21 PREGNANCY
}

\author{
Jonnie A. Lane
}

\author{
Thesis submitted to the \\ College of Agriculture, Forestry and Consumer Sciences \\ at West Virginia University \\ in partial fulfillment of the requirements \\ for the degree of
}

Master of Science

In

Genetics and Developmental Biology

\author{
Joginder Nath, Ph.D., Chair \\ Sharon L. Wenger, Ph.D. \\ Leo R. Brancazio M.D.
}

Department of Genetics and Developmental Biology

Morgantown, West Virginia 2000

Keywords: Maternal Serum Triple Screen, Trisomy 21, Ultrasound, Amniocentesis Copyright 2000 Jonnie A. Lane 


\title{
ABSTRACT \\ EVALUATION OF MATERNAL SERUM TRIPLE SCREEN AS AN IDENTIFIER OF TRISOMY 21 PREGNANCY
}

\author{
Jonnie A. Lane
}

\begin{abstract}
Maternal serum triple screen is used to identify women under 35 years of age who are at an increased risk of having a fetus with Down syndrome. The screen identifies $5 \%$ of all women tested as being at an increased risk but only 2-3\% of these women actually have a fetus with chromosome abnormalities, indicating a high false positive rate. Preliminary evaluation of 300 cases indicated that the number of trisomic fetuses identified by maternal serum triple screen in our population was considerably lower than expected. Medical records for 900 cases referred for maternal serum triple screen and maternal age were reviewed for maternal age, individual risk of carrying a fetus with Down syndrome, karyotype results and ultrasound abnormalities. Among the maternal serum screen group, $0.77 \%$ had an abnormal karyotype and among the maternal age group, $1.2 \%$ had an abnormal karyotype. These percentages of abnormal karyotypes are not significantly different from each other or the expected value. Statistical comparisons of risk figures between the two populations indicate that they are also not significantly different. While $3 \%$ of all cases with normal karyotypes had ultrasounds with one or more abnormalities, $33 \%$ of cases with abnormal karyotypes had an abnormal ultrasound. The data suggest that ultrasound may be helpful in identifying fetuses with Down syndrome. While maintaining the same detection rate of Down syndrome fetuses it would also decrease the number of invasive procedures performed.
\end{abstract}




\section{TABLE OF CONTENTS}

$\begin{array}{lc}\text { Abstract } & \begin{array}{c}\text { Page } \\ \text { ii }\end{array} \\ \text { Table of Contents } & \text { iii } \\ \text { List of Tables } & \text { iv } \\ \text { Introduction } & 1 \\ \text { Materials and Methods } & 10 \\ \text { Results } & 12 \\ \text { Discussion } & 22 \\ \text { Bibliography } & 27 \\ \text { Appendix A - Patient Data } & 30\end{array}$




\section{LIST OF TABLES}

Page

Table 1. Abnormal karyotypes from prenatal testing of at risk populations and rank of abnormal karyotypes among 900 by individual risk figures

Table 2. Rank of risk figures from both populations

Table 3. Abnormal karyotypes in at risk prenatal samples

Table 4. Observed and expected abnormal karyotypes

Table 5. Observed and expected abnormal karyotypes in maternal serum triple screen population

Table 6. Ultrasound abnormalities in both populations

Table 7 Risk calculation incorporating ultrasound 


\section{INTRODUCTION}

\section{DOWN SYNDROME}

Down syndrome or trisomy 21 is the most common chromosome abnormality, occurring in 1/700 live births (Ramzi et al., 1999). The characteristic features include mental retardation, epicanthal folds, short stature, protruding tongue, a single palmer (simian) crease, hypotonia and an increased risk of having congenital malformations of the heart and kidneys (Jones, 1997). The extra chromosome 21 present in individuals with Down syndrome results from an error in meiotic division called nondisjunction which is the failure of a pair of homologous chromosomes to separate. This results in unequal distribution of the chromosomes to the daughter cells, such that one gamete has both homologues and the other has neither homologue. Fertilization of a gamete with an extra chromosome produces a zygote with 47 chromosomes that is trisomic for chromosome 21. Using molecular studies, investigations have shown that most cases of trisomy 21 are due to maternal meiotic error (Ramzi et al., 1999). Population studies indicate that a woman's risk of carrying a child with Down syndrome increases with maternal age. 


\section{MATERNAL AGE}

Numerical risks of having a fetus with Down syndrome due to maternal age.

\begin{tabular}{|c|c|}
\hline Mother's Age at expected date of delivery & Risk of having a baby with Down syndrome \\
\hline 35 & $1: 245$ \\
\hline 36 & $1: 189$ \\
\hline 37 & $1: 147$ \\
\hline 38 & $1: 114$ \\
\hline 39 & $1: 89$ \\
\hline 40 & $1: 69$ \\
\hline 41 & $1: 53$ \\
\hline 42 & $1: 41$ \\
\hline 43 & $1: 32$ \\
\hline 44 & $1: 25$ \\
\hline 45 & $1: 19$ \\
\hline 46 & $1: 15$ \\
\hline 47 & $1: 11$ \\
\hline & \\
\hline & \\
\hline
\end{tabular}

(Hook et al., 1983)

As maternal age increases, the risk of Down syndrome pregnancy also increases. There are many different hypotheses to explain this correlation. It is known that at the time of birth, a woman's ovaries contain all the germ cells she will ever have. Primary oocytes are stopped at prophase of meiosis I. Only when signaled by hormones at the time of ovulation does the primary oocyte resume meiosis. 
Chiasmata play a role in holding homologous chromosomes together at prophase of meiosis I. The number of chiasmata in the meiotic chromosomes of oocytes decline as maternal age increases. This could cause homologues to separate prematurely and act as univalents, with independent segregation which could result in trisomy 21 (Thompson et al., 1991).

One hypothesis is that some parents of Down syndrome children may have a defect in microtubular polymerization, causing an increased rate of hyperploidy in all dividing cells which is expressed in both meiotic and mitotic cells of the affected individuals. This would result in random segregation of displaced chromosomes from the spindle fiber, with an increased chance of an extra chromosome 21 in the gamete (Ford, 1984).

Another hypothesis has been presented that there is a maternal screening process in the post recognition phase of pregnancy and the failure of this process increases with age. The rate of nondisjunction is the same regardless of age, however in the majority of younger women, trisomic zygotes are recognized and rejected, but as women become older the selection process is relaxed and the trisomic zygote is not rejected (Stein et al., 1986).

In 1989, the limited oocyte pool hypothesis was proposed, which states that a defective oocyte has a greater probability of becoming the dominant follicle in older women because of the smaller number of oocytes available as a woman ages (Warburton, 1989). If this oocyte becomes the dominant follicle and is fertilized, this type of oocyte has an increased chance of undergoing nondisjunction. This lead to the hypothesis that women who have a reduced number of oocytes due to other reasons may be at an increased risk for a trisomy 21 pregnancy. In a recent study of Down syndrome infants, blood 
samples were collected from infants and their parents for analysis to determine the origin of chromosomal error. Mothers were then asked if they had an ovary removed before conception. The authors showed that a significantly greater number of women with children who had Down syndrome possessed only one functional ovary (7/189) than mothers who had two (1/329). This suggested that women who have one ovary should be offered prenatal testing for chromosome abnormalities (Freeman et al., 2000). A recent study showed that the median age at menopause is $\sim 1$ year earlier for women with trisomic pregnancies than among women with normal pregnancies, suggesting that a limited oocyte pool contributes to a trisomic pregnancy (Kline et al., 2000).

The majority of trisomy 21 fetuses are due to nondisjunction in the ovum because nearly $90 \%$ of the cases with Down syndrome have an additional maternal chromosome (Hassold and Sherman, 2000). Genetic mapping studies allowed the authors to identify altered numbers and positions of meiotic recombination events. The authors hypothesized that chromosome nondisjunction requires two events. The first is the establishment of a bivalent vulnerable to nondisjunction during prophase I and the second, which is dependent on age, is the abnormal processing of the vulnerable bivalent during meiosis

I or II. The authors' findings suggested that most nondisjunctional events are initiated during meiosis I and then resolved at either meiosis I or meiosis II.

\section{MATERNAL SERUM TRIPLE SCREEN}

Maternal serum triple screening is a prenatal test for non-at-risk pregnancies ( $<35$ years of age) and is performed at 16-22 weeks of gestation (Wald et al., 1997). Maternal serum screening is also useful in calculating a more accurate risk of a Down syndrome fetus and reduce the need for 
amniocentesis in women 35 years of age or older (Haddow et al., 1994). This test is not diagnostic but rather screens for at risk pregnancies. It is designed to identify $5 \%$ of all women tested as being at a high risk for carrying a fetus with Down syndrome. The screen can identify $60 \%$ of Down syndrome fetuses in this age group that would normally go undetected (Wald et al., 1999). The screen is based on concentrations of various biochemical markers in the maternal serum that are altered if the fetus has Down syndrome. Down syndrome pregnancy is associated with low levels of maternal serum alpha fetoprotein (AFP) and unconjugated estriol (uE3) and high concentrations of human chorionic gonadotropin (hCG) (Wald, et al., 1999).

AFP is the principle plasma protein which is normally produced by the fetus. Alpha fetoprotein is produced by the yolk sac early in gestation and at approximately 11.5 weeks of gestation its production is taken over by the fetal liver and gastrointestinal system. AFP is delivered into the amniotic fluid by fetal urination and is degraded by fetal digestion and swallowing. AFP concentrations peak in fetal blood at 12-14 weeks, peak in amniotic fluid at 13 weeks and peak in maternal serum at 32 weeks. AFP levels are reduced approximately $25 \%$ in the serum of a women with a Down syndrome fetus due to congenital abnormalities that lead to reduced synthesis by the fetal liver and reduced excretion by the kidneys (Wald et al., 1991).

$\mathrm{uE} 3$ is a steroid requiring fetal adrenal and liver function for its synthesis. It is approximately 25$30 \%$ lower in serum of women with a Down syndrome fetus because of congenital abnormalities of the liver. The primary purpose of measuring $\mathrm{uE} 3$ in addition to AFP in the screening test is to improve the detection rate of Down syndrome in fetuses, which can reduce false positives by $25 \%$ (Phillips et al., 
1992).

hCG, a hormone secreted by the placenta and detected in maternal serum soon after the fertilized ovum is implanted, is the most informative maternal serum marker for Down syndrome to date. Concentrations of hCG in maternal serum rise during the first 10 weeks, decrease during the next 8 weeks and then remain stable (Trent, 1995). Maternal serum hCG has been reported to be twice as high in pregnancies with Down syndrome fetuses when compared to normal pregnancies. It remains unknown why hCG levels increase in pregnancies affected with Down syndrome (Bogart et al., 1987).

Concentrations of the biochemical markers are presented as multiples of the median (MoMs) of the normal value at a specific gestational age. Algorithms have been developed to predict a woman's risk of carrying a fetus with Down syndrome using her age, serum markers, gestational age, and other demographic information. Gestational diabetes, maternal weight, maternal race and smoking affect serum marker concentration values. If the mother is heavier she will have a lower AFP due to increased blood volume, if she is black she will have a higher AFP and if she has gestational diabetes or is a nonsmoker she will have a lower AFP (Wald et al., 1992). These factors must be considered and the MoM must be adjusted accordingly as part of the equation, for an accurate estimate. This is used as a statistical tool because it decreases the effect of extreme values. Using algorithms also allows for the fact that marker concentrations vary at different stages of a pregnancy.

$\mathrm{MoM}=\quad$ Biochemical marker concentration Median for the patient's week of gestation 
It is important that the gestational age of the fetus be correct, in order to accurately calculate the MoMs since concentrations of biochemical markers vary during the second trimester. Ultrasound during the second trimester is advantageous for gestational dating. It is helpful for a woman at increased risk for carrying a fetus with Down syndrome to have an ultrasound performed to check for physical abnormalities and confirm the gestational age. Amniocentesis can then be offered as a follow-up test for fetal karyotyping. In general the maternal serum levels in a pregnancy with Down syndrome are, 0.7 MoMs for AFP, 2.0 MoMs for hCG and 0.7 MoMs for uE3.

\section{Risk of a fetus having Down syndrome due to maternal serum marker concentrations and gestational age}

\begin{tabular}{|l|l|l|l|l|l|}
\hline \multicolumn{3}{|c}{ Marker Levels } & Risk of Down syndrome if gestational age is \\
\hline MS-AFP & MS-hCG & MS-uE3 & 16 & 17 & 18 \\
\hline 0.5 & (MoMs) & (MoMs) & weeks & weeks & weeks \\
\hline 0.5 & 2.0 & 0.5 & $1: 74$ & $1: 28$ & $1: 12$ \\
\hline 2.0 & 1.0 & 1.0 & $1: 490$ & $1: 280$ & $1: 170$ \\
\hline 2.0 & 0.5 & 0.5 & $1: 8,300$ & $1: 2,600$ & $1: 890$ \\
\hline
\end{tabular}

(Trent, 1995)

Maternal serum triple screen is designed to identify $5 \%$ of women at an increased risk for having a child with Down syndrome. Of those women that choose follow-up amniocentesis for analysis 
of chromosomes, only 2-3\% of pregnancies actually have chromosomal abnormalities (Phillips et al., 1992, Valerio et al., 1996). This indicates a high false positive rate for the screening test. This could mean that many women may be unnecessarily referred for amniocentesis, a procedure which can cause anxiety for the pregnant woman while waiting for the karyotype results (Salonen et al., 1996).

\section{PRENATAL SCREENING}

The approach to prenatal screening for Down syndrome is to first estimate a woman's risk for having an affected pregnancy. Women with a risk above a specified level (1/300) are considered at a high risk due to age or maternal serum triple screen and are counseled on their options. The level of $1 / 300$ is used because this is the risk of pregnancy loss in the second trimester due to the amniocentesis procedure. Women are then offered prenatal testing which can include chorionic villus sampling (CVS) or amniocentesis.

Prior to CVS or amniocentesis, an ultrasound is performed to locate the placenta and position of the fetus. The age of the fetus is also calculated by measuring the circumference of the head, biparietal diameter, abdomen and the length of the femur. It has been found that second trimester ultrasound can also identify $50-90 \%$ of trisomy 21 fetuses by detecting physical abnormalities (Ginsberg et al., 1990; Benacerraf et al., 1991). These abnormalities can include a short humerus, increased nuchal fold thickening, echogenic bowel, clinodactyly and abnormalities of the heart and kidneys. This may be a useful adjunct to pregnancies at high risk for trisomy 21 (Lockwood et al., 1991). 


\section{PURPOSE}

Preliminary evaluation of prenatal testing from the cytogenetic laboratory at WVU Hospitals identified 2/300 abnormal karyotypes in women at high risk due to maternal serum triple screen and 4/300 abnormal karyotypes for advanced maternal age. From this preliminary data we hypothesized that our population had a higher false positive rate than what is reported in the literature. The goal of this project was to reevaluate the number of trisomic fetuses identified by maternal serum triple screen in our population and test if ultrasound can be used to increase the rate of identifying Down syndrome fetuses. 


\section{MATERIALS AND METHODS}

Studies performed on amniotic fluid cells in the cytogenetics laboratory at WVU Hospitals from 1992 to 1999 were used for this project. In a preliminary evaluation of 300 cases, 2 abnormal karyotypes were found among the maternal serum triple screen group and 4 abnormal karyotypes were found among the maternal age group. To determine the sample size needed to detect a statistical difference between these populations, the Krebb's sample size determination test was used. At a significance level of 0.05, the sample size must be 639 or greater. Since 1992, 900 patients at increased risk for having a child with Down syndrome through maternal serum triple screening were identified. The control group consisted of 900 patient samples received within a similar time frame for increased risk due to maternal age ( $\geq 35$ years of age). For each patient, information was obtained from data bases in Clinical Cytogenetics Laboratory and patient medical records which included woman's age, the numerical risk of having a child with Down syndrome, any abnormalities found by ultrasonography at the time of amniocentesis and the karyotype of the fetus.

Chi square tests were performed to compare differences between the two populations for

chromosomally abnormal karyotypes, the risk for having a child with Down syndrome and ultrasound 
results. Chi square tests were also performed to test the different parameters of the maternal serum triple screen population.

A Mann-Whitney U test was performed to compare the risks in the two populations. Using the Mann-Whitney U test, a non-parametric ranking test, two independent populations of small unequal sample sizes can be compared. The Mann-Whitney $U$ test ranks all the risk figure values from low to high, without any reference to the group to which the value belongs. The smallest number gets a rank of 1. The value of $U$ is obtained by counting the number of times each risk figure in the advanced maternal age population precedes a risk figure in the maternal triple screen population in the ranking (in bold print in Table 2 ). If the values of the two populations are very different, the $U$ value will be small. 


\section{RESULTS}

The data collected included risk figures, karyotypes, maternal age and ultrasound results.

Comparisons were made between the two populations The differences between the two populations and differences between the number of observed and expected abnormal karyotypes in the maternal serum triple screen population were analyzed. 
Table 1

Abnormal Karyotypes From Prenatal Testing

Of At Risk Population

Karyotype

$\begin{array}{cccc}\begin{array}{c}\text { Maternal } \\ \text { Age }\end{array} & \begin{array}{c}\text { Individual } \\ \text { Risk Figure }\end{array} & \begin{array}{c}\text { Ultrasound } \\ \text { Abnormality }\end{array} & \begin{array}{c}\text { Rank } \\ \text { Among } \\ \mathbf{9 0 0}\end{array}\end{array}$

Maternal Serum Triple Screen

$\begin{array}{ccccc}47, \mathrm{XY},+18 & 24 & 0.0213 & 0 & 841 \\ 47, \mathrm{XY},+21 & 17 & 0.0125 & 0 & 775 \\ 47, \mathrm{XY},+21 & 30 & 0.0417 & 0 & 875-876 \\ 47, \mathrm{XY},+21 & 29 & 0.0057 & 1 & 536 \\ 47, \mathrm{XY},+21 & 29 & 0.0164 & 0 & 815 \\ 47, \mathrm{XX},+21 & 29 & 0.0086 & 0 & 686 \\ 47, \mathrm{XX},+21 & 32 & 0.0417 & 1 & 875-876\end{array}$

Advanced Maternal Age

\begin{tabular}{lllll}
$47, \mathrm{XX},+21$ & 37 & 0.0045 & 0 & $390-466$ \\
$47, \mathrm{XX},+21$ & 37 & 0.0045 & 0 & $390-466$ \\
$47, \mathrm{XX},+18$ & 39 & 0.0074 & 0 & $615-694$ \\
$47, \mathrm{XX},+18$ & 42 & 0.0159 & 0 & $843-845$ \\
$47, \mathrm{XX},+21$ & 40 & 0.0094 & 1 & $715-774$ \\
\hline
\end{tabular}




\begin{tabular}{ccccc}
\hline $47, \mathrm{XY},+18$ & 47 & 0.0617 & 1 & 893 \\
$47, \mathrm{XY},+21$ & 40 & 0.0094 & 1 & $715-774$ \\
$47, \mathrm{XY},+21$ & 39 & 0.0074 & 0 & $615-694$ \\
$47, \mathrm{XXX}$ & 41 & 0.0122 & 0 & 812 \\
$47, \mathrm{XX},+21$ & 37 & 0.0045 & 0 & $390-466$ \\
$47, \mathrm{XX},+21$ & 38 & 0.0057 & 0 & 587 \\
$47, \mathrm{XX},+18$ & 42 & 0.0159 & 2 & $843-845$ \\
\hline
\end{tabular}

$\left(\mathrm{X}^{2}=1.288 ;\right.$ d.f. $\left.=3 ; \mathrm{p}>0.05\right)$

Table 1 shows cases with abnormal karyotypes collected among 900 patients referred for amniocentesis due to either abnormal maternal serum triple screen ( $<35$ years of age) or advanced maternal age ( $\geq 35$ years of age). Cases with abnormal karyotypes are listed with maternal age, risk figure for having a fetus with Down syndrome and rank of risk figure among 900 and the number of abnormalities found during ultrasound. A chi square goodness of fit test was used to compare the risk figures and abnormal karyotypes between the two populations. There was no significant difference between risk and abnormal karyotype. No significance however could be due to a low number of abnormal karyotypes.

The triple screen cases are all found in the top 50\% rank of risk figures while $75 \%$ of maternal age cases are in the top 50\% (>450 rank). To determine if there was a difference between the two populations, the cases from Table 1 were ranked according to risk figures. 
Table 2

Rank of Risk Figures

From Both Populations

\begin{tabular}{lcclc}
\hline Population & Risk Figure & Rank & $\begin{array}{l}\text { Number of times risk figure in maternal age } \\
\text { population precedes the risk figure in the triple } \\
\text { screen population }\end{array}$ \\
Advanced Maternal Age & 0.0045 & 1 & 0 \\
Advanced Maternal Age & 0.0045 & 2 & 0 \\
Advanced Maternal Age & 0.0045 & 3 & 0 \\
Maternal Triple Screen & 0.0057 & 4 & 1 \\
Advanced Maternal Age & 0.0074 & 5 & 1 \\
Advanced Maternal Age & 0.0074 & 6 & 1 \\
Advanced Maternal Age & 0.0074 & 7 & 2 \\
Maternal Triple Screen & 0.0086 & 8 & 2 \\
Advanced Maternal Age & 0.0094 & 9 & 2 \\
Advanced Maternal Age & 0.094 & 10 & 3 \\
Advanced Maternal Age & 0.0122 & 11 & 12 & \\
Maternal Triple Screen & 0.0125 & 13 & \\
Advanced Maternal Age & 0.0159 & 13 & \\
\hline
\end{tabular}




\begin{tabular}{llll}
\hline Advanced Maternal Age & 0.0159 & 14 & 3 \\
Maternal Triple Screen & 0.0164 & 15 & \\
Maternal Triple Screen & 0.0203 & 16 & \\
Maternal Triple Screen & 0.0417 & 17 & 7 \\
Maternal Triple Screen & 0.0417 & 18 & \\
Advanced Maternal Age & 0.0617 & 19 & \\
\hline
\end{tabular}

Using a Mann-Whitney U test, at a significance level of 0.05 with sample sizes of 7 and 12 , the $\mathrm{U}$ value must be 18 or less. The $\mathrm{U}$ value was 22 , indicating that there is not a significant difference between the risk figures in the two populations.

Table 3

Abnormal Karyotypes

In At Risk Prenatal Samples

\begin{tabular}{lccc} 
Karyotype & Advanced Maternal Age & Maternal Serum Triple Screen & Total \\
Abnormal & 12 & 7 & 19 \\
Normal & 888 & 893 & 1781 \\
Total & 900 & 900 & 1800 \\
\hline
\end{tabular}

$\left(\mathrm{X}^{2}=1.82 ;\right.$ d.f. $\left.=1 ; \mathrm{p}>0.05\right)$

To compare the number of abnormal karyotypes in the two populations, a chi square test was performed. The number of abnormal karyotypes in the two populations is not statistically different. 
Table 4

Observed and Expected

Abnormal Karyotypes

\begin{tabular}{lccc}
\hline & Abnormal Karyotype & Normal Karyotype & Total \\
Observed & 7 & 893 & 900 \\
Expected & 13 & 887 & 900 \\
Total & 20 & 1780 & 1800 \\
\hline $\mathrm{X}^{2}=1.82 ; \mathrm{df}=1 ;(\mathrm{p}>0.05)$
\end{tabular}

$\left(\mathrm{X}^{2}=1.82 ;\right.$ d.f. $\left.=1 ; \mathrm{p}>0.05\right)$

In our maternal serum triple screen population, $0.77 \%$ had abnormal karyotypes. Based on

literature with a 5\% false positive rate, a minimum of $2 \%$ abnormal karyotypes would be expected. A 
chi square test was used to see if there was a difference between observed abnormal karyotypes and expected based on literature. There is not a significant difference between the number of observed abnormal karyotypes and the expected number of abnormal karyotypes.

Table 5

Observed and Expected Abnormal Karyotypes

in Maternal Serum Triple Screen Population

\begin{tabular}{lccc}
\hline & Abnormal Karyotype & Normal Karyotype & Total \\
\# Observed & 7 & 893 & 900 \\
\# Expected & 10 & 890 & 900 \\
Total & 17 & 1783 & 1800 \\
\hline$\left(\mathrm{X}^{2}=0.53 ;\right.$ d.f. $\left.=1 ; \mathrm{p}>0.975\right)$ & & &
\end{tabular}

A chi square test was used to determine if the number of abnormal karyotypes that should be 
observed, based on the total of the risk figures for the 900 maternal serum triple screen population which totals 10.31 , is being observed. There is not a significant difference between the number of observed and expected abnormal karyotypes based on risk figures in the maternal serum triple screen population.

Table 6

Ultrasound Abnormalities In Both Populations

\begin{tabular}{lccc}
\hline & Abnormal Karyotype & Normal Karyotype & Total \\
$\begin{array}{l}\text { Abnormal } \\
\text { Sonography }\end{array}$ & $6(33 \%)$ & $53(3 \%)$ & 59 \\
$\begin{array}{l}\text { Normal } \\
\text { Sonography }\end{array}$ & 13 & 1728 & 1741 \\
Total & 19 & 1781 & 1800 \\
\hline
\end{tabular}


$\left(X^{2}=48.514 ;\right.$ d.f. $\left.=1 ; p<0.005\right)$

To determine if ultrasound can increase the detection rate of abnormal pregnancies, a chisquare likelihood ratio test was used to compare the abnormal and normal karyotypes with abnormal and normal sonography. The results are statistically significantly different, indicating that ultrasound abnormalities are seen more often in cases with abnormal karyotypes than in cases with normal karyotypes.

Table 7

Risk Calculation Incorporating Ultrasound Results 


\section{Weight factor for cases with normal ultrasound}

$\frac{\text { Average risk for normal sonography }}{\text { Average risk of } 1800 \text { cases }} \quad \frac{0.00695}{0.008637}=0.805$

\section{Weight factor for cases with abnormal ultrasound}

$\underline{\text { Average risk for abnormal sonography }} \quad \underline{0.1183}=13.697$

Average risk of 1800 cases $\quad 0.008637$

The average risk including sonography for cases with normal ultrasound is the risk of having a normal ultrasound but an abnormal karyotype. The average risk including sonography for cases with an abnormal ultrasound is the risk of having an abnormal ultrasound and abnormal karyotype. By including the weight factor for cases, the risk will be reduced for women with normal ultrasound and 650 amniocentesis procedures could be eliminated. These cases did not include any chromosomally abnormal fetuses. Of the 650 amniocentesis procedures that could be eliminated, 250 are from the maternal serum triple screen population. Reducing the number of amniocentesis procedures in this population from 900 to 650 would decrease the percentage of the population considered to be at high risk due to triple screen from $7.2 \%$ to $5.2 \%$ and therefore increase our rate of detection.

To assess why there is a small number of abnormal fetuses in our study population, data from 75 women who screened positive with maternal serum triple screen but refused amniocentesis was collected. All 75 women had a karyotypically normal fetus. 


\section{DISCUSSION}

A screening test is used to identify a group which is at risk for a particular characteristic rather 
than being a diagnostic tool. The maternal serum triple screen using a 5\% cutoff will detect $60 \%$ of fetuses with Down syndrome that would normally not be identified (Phillips et al., 1992). With 5\% of the population considered to be at high risk for having a child with Down syndrome due to abnormal maternal serum triple screen, the expected number of abnormal fetuses is $2-3 \%$. In our study population, a lower number of abnormal fetuses is expected because $7.2 \%$ of the population is considered to be at high risk due to the cutoff used by our clinical chemistry labs for triple screen. An increase of $2.2 \%$ in high risk pregnancies increases the number of false positives, which subsequently decreases the percent of abnormal fetuses that would be detected. Therefore, in our population, the expected number would be $1.4 \%$ or 13 abnormal fetuses. The false positive rate in our population is higher than what is reported in literature, which is based on a screen result of greater than 1/250 (Wald et al., 1999). In our population, 1/300 is considered to be at high risk, which would explain the higher false positive rate in our population. Because of the small number of women who have abnormal fetuses, we suggest that changing the cutoff rate for triple screen should be considered. Comparisons were made between observed and expected abnormal karyotypes in the triple screen population based a 1/300 risk cutoff (Table 4) and the total of individual risk figures (Table 5). There was no significant difference between the number of observed and expected abnormal karyotypes (Tables 4 and 5). The frequency of abnormal karyotypes in the two populations were also compared and found not to be significantly statistically different (Table 3). According to literature, $2 \%$ of women of advanced maternal age have a fetus with an abnormal karyotype (Philips et al., 1992 and Valerio et al., 1996). This percentage is similar to the $1.4 \%$ expected from the maternal serum triple screen. With those detection 
rates, it would be expected that the number of women who would have abnormal karyotypes in the two populations would not be statistically different.

Comparisons of the number of abnormal karyotypes and the risk figures were made between the two populations. There was no significant difference. However, when looking at the data, there seems to be a correlation between higher risk figures and abnormal karyotypes in the maternal serum triple screen group. The lowest risk figure ranks 536 among 900 (Table 1). The risk figures were also compared between the two populations and there was no significant difference (Table 2).

Ultrasound abnormalities were found more often in fetuses with an abnormal karyotype versus a normal karyotype which was statistically significant at $\mathrm{p}<0.005$ (Table 6). Physical abnormalities of the fetus with Down syndrome observed in the first trimester include shortened long bone lengths, increased nuchal thickening, clinodactyly and echogenic bowel along with gross physical abnormalities (Daren et al., 1998). The identification of subtle abnormalities during ultrasonographic examinations improve the detection rate of Down syndrome. It has also been suggested that both first and second trimester ultrasound may be useful in identifying pregnancies at risk for Down syndrome (Wald., 1999). By combining maternal serum screening and ultrasound, a higher percentage of Down syndrome fetuses have been identified (Lockwood et al., 1991). A goodness of fit test comparing the number of normal and abnormal karyotypes with normal and abnormal sonography was statistically significant at $\mathrm{p}<0.005$, indicating that ultrasound abnormalities are found more often in cases with abnormal karyotypes. If second trimester ultrasound could be used to identify fetal abnormalities in women at risk of having a Down syndrome pregnancy, the false positive rate would decrease and the detection rate of abnormal 
fetuses would increase. Overall, the risk for an abnormal karyotype decreased if the ultrasound was normal, but substantially increased if the ultrasound was abnormal. A weight factor was determined for cases with both normal and abnormal sonography (Table 7). Multiplying the risk factor for maternal serum triple screen or maternal age by the weight factor for normal ultrasound (0.805) will decrease the individual's risk for having a Down syndrome fetus, which should decrease the number of unnecessary amniocenteses. Multiplying the weight factor for abnormal sonography (13.697) by the risk of a Down syndrome fetus will increase the individual's risk and therefore the need for amniocentesis. In our study population, $650(36.1 \%)$ amniocentesis procedures could be eliminated without missing cases with abnormal karyotypes by incorporating the weight factor for sonography. Integrated screening has been proposed as a more sensitive method for identifying fetuses with Down syndrome. The integrated test is based on maternal serum measurements obtained during both the first and second trimesters and provides a single estimate of a woman's risk of having a child with Down syndrome. The purpose of this test is to detect more Down syndrome cases and have a lower false positive than the second trimester triple screen (Wald et al., 1999). The authors reported that by replacing the second trimester triple screen with the integrated screen, the detection rate of Down syndrome fetuses was $16 \%$ higher and the false positive rate was lower for this study group. Consequently, the number of invasive diagnostic procedures would decrease by $80 \%$, reducing the loss of normal fetuses due to the amniocentesis procedure by 20\% (Wald et al., 1999).

Another screening test, the quad test, is now being conducted at some facilities. This screen measures inhibin $\mathrm{A}$ in addition to serum $\mathrm{AFP}, \mathrm{hCG}$ and $\mathrm{uE} 3$ during the second trimester. Inhibin $\mathrm{A}$ is a 
placental hormone that is elevated in pregnancies with a Down syndrome fetus. By adding the fourth marker, the detection rate of Down syndrome increases by $10 \%$. However, this screen is not being widely used because of the technical challenges it presents. The assay used by laboratories measuring levels of inhibin A exhibits broad variability from one batch of reagents to the next and there are many steps in the testing process that can vary from day to day. This is a screen that requires good laboratory technique and attention to environmental changes which requires supervision, increasing the cost (King., 2000)

The detection rate of Down syndrome in our population (0.77\%), although not significantly different, is lower than expected (1.4\%). Cytogenetic studies that were performed on newborns from women who screened positive for maternal serum triple screen but refused amniocentesis showed no abnormal karyotypes. This suggests that our low detection rate is not due to missed abnormal cases. Therefore our low detection rate may be due to other factors such as differences in our study population. One possibility is that women under age 35 may choose not to undergo triple screening. Women, who have never terminated a pregnancy, were religious or Spanish-speaking Latino, were more likely to refuse testing (Press and Browner., 1998). It was also reported that women who have had a triple screen positive result in a previous pregnancy were more likely to refuse maternal serum screening in their next pregnancy due to the anxiety caused by a screen positive result (Rausch et al., 2000).

Individual risks of having a child with Down syndrome in the two populations were not significantly different from each other (Table 1). Similar findings have been found in a study of pregnant 
Japanese women that tested the accuracy of their predicted risk from maternal serum triple screening for Down syndrome. The correlation between the predicted risks and the occurrence of Down syndrome was very high ( $\mathrm{r}=0.98)$ (Onda et al., 1998). Another study showed similar results when the mean predicted risks for Down syndrome of pregnant women identified by maternal serum triple screen were compared. The comparison showed that the estimated risks from the triple test were accurate (Wald et al., 1996). This study lead to the evaluation of the accuracy of assigned risks in a screening population. The results confirmed that the calculation of assigned risks is accurate (Canick and Rish., 1998).

Current testing can be improved by using second trimester ultrasound in conjunction with maternal serum triple screen. Adjusting the risk of having a karyotypically abnormal fetus by including sonography decreased the number of amniocentesis procedures in our study population by $36.1 \%$. By adjusting the risk figure based on sonography, the number of unnecessary amniocenteses would decrease, thereby improving patient care by reducing the risk of pregnancy loss due to the amniocentesis procedure.

\section{BIBLIOGRAPHY}


Benacerraf BR, Neuberg D, Bromley B, Frigoletto FD Jr (1991): Sonographic scoring index for prenatal detection of chromosomal abnormalities. J Ultrasound Med 11:449-458.

Bogart MH, Pandian MR, Jones OW (1987): Abnormal maternal serum chorionic gonadotropin levels in pregnancies with fetal chromosome abnormalities. Prenat Diagn. 9:623-630.

Canick JA and Rish S (1998): The accuracy of assigned risks in maternal serum screening. Prenat Diagn. 18:405-415.

Clinical Chemistry Lab (2000): West Virginia University Hospital.

Daren O, Mahoney MJ, Copel JA, Bahado-Singh RO (1998): Subtle ultrasonographic anomalies: Do they improve the Down syndrome detection rate? Am J Obstet Gynecol 178:441-445.

Ford JH (1984): Spindle microtubular dysfunction in mothers of Down syndrome children. Hum Genet 68:295-298.

Freeman SB, Yang Q, Allran K, Taft LF, Sherman SL (2000): Women with a reduced ovarian complement may have an increased risk for a child with Down syndrome. Am J Hum Genet 66:1680-1683.

Ginsberg N, Cadkin A, Pergament H, Verlinksy Y (1990): Ultrasonographic detection of the secondtrimester fetus with trisomy 18 and trisomy 21. Am J Obstet Gynecol 163:11861190.

Haddow JE, Palomaki GE, Knight GJ, Cunningham GC, Lustig LS, Boyd PA (1994): Reducing the need for amniocentesis in women 35 years of age or older with serum markers for screening. $\mathrm{N}$ Engl J Med 330(16):1114-8.

Hassold T, Sherman S (2000): Down syndrome: genetic recombination and the origin of the extra chromosome 21. Clin Genet 57: 95-100.

Hook EB, Cross PK, Schreinemachers DM (1983): Chromosomal abnormality rates at amniocentesis and liveborn infants. J Am Med Assoc 249(15):2034-8.

Jones (1997): Smith's recognizable patterns of human malformation, ed. . WB Saunders Company. P. 8-10.

King, D (2000): Advance for medical laboratory professionals 12(10) P. 9. 
Kline J, Kinney A, Levin B, Warburton D (2000): Trisomic pregnancy and earlier age at menopause. Am J Hum Genet 67:395-404.

Lockwood CJ, Lynch L, Berkowitz RL (1991): Ultrasonographic screening for the Down syndrome fetus. Am J. Obstet Gynecol 165:349-352.

Phillips OP, Elias S, Shulman LP, Andersen RN, Morgan CD, Simpson JL (1992): Maternal serum screening for fetal Down syndrome in women less than 35 years of age using alpha-fetoprotein, hCG, and unconjugated estriol: a prospective 2-year study. Obstet Gynecol 80:353-358.

Press N and Browner CH (1998): Characteristics of women who refuse an offer of prenatal diagnosis: Data from the California maternal serum alpha fetoprotein blood test experience. Am J of Med Genetics 78:433-445.

Ramzi SC, Vinay K, Tucker C (1999): Robbins Pathologic Basis of Disease, $6^{\text {th }}$ edition. Philadelphia, PA. WB Saunders Company 170-171.

Rausch DN, Lambert-Messerlian GM, Canick JA (2000): Participation in maternal serum screening following screen positive results in a previous pregnancy. J Med Screen 7(1):4-6.

Salonen, R, Kurki L, Lappalainen M (1996): Experiences of mothers participating in maternal serum screening for Down's syndrome. Eur J Hum Genet 4:113-119.

Stein Z, Stein W, Susser M (1986): Attrition of trisomies as a maternal screening device. The Lancelet. April 26: 944-946.

Thompson MW, McInnes RR, Willard HF (1991): Thompson \& Thompson Genetics in Medicine 5th ed. WB Sanders Co., Philadelphia, PA. pp. 407-409.

Trent RJ (1995): Handbook of Prenatal Diagnosis. United States. Cambridge University Press. 15-23, 198.

Valerio D, Aiello R, Altieri V, Fagnoni P (1996): Maternal serum screening of fetal chromosomal Abnormalities by AFP, uE3, hCG and free-beta hCG. Prospective and retrospective results. Minerva Ginecol 48:169-173.

Wald N, Cuckle H, Wu T, George L (1991): Maternal Serum Unconjugated Oestriol and Human Chorionic Gonadotrophin Levels in Twin Pregnancies: Implications for Screening for Down Syndrome. Br J Obstet Gynecol 98:905-908. 
Wald NJ, Cuckle HS, Densem JW, Kennard A, Smith D (1992): Maternal serum screening for Down syndrome: The effect of routine ultrasound scan on determination of gestational age and adjustment for maternal weight. British J of Obstet Gynecol 99:144-149.

Wald NJ, Hackshaw AK, Huttly W, Kennard A (1996): Empirical validation of risk screening for Down's syndrome. J Med Screen 3(4):185-187.

Wald NJ, Kennard A, Hackshaw A, McGuire A (1997): Antenatal screening for Down's syndrome, J Med Screen 4:181-246.

Wald NJ, Watt HC Hackshaw AK (1999): Integrated Screening for Down Syndrome based on tests performed during the first and second trimesters. N Engl J Med 341:461-467.

Warburton (1989): The effect of maternal age on the frequency of trisomy: change in meiosis or in utero selection? Molecular and cytogenetic studies of nondisjunction. Liss, New York, p. 165-181. 


\section{Appendix A \\ PATIENT DATA}

\begin{tabular}{|c|c|c|c|c|c|c|c|c|c|}
\hline $\begin{array}{c}\text { Risk for } \\
\text { Trisomy } 21 \\
\end{array}$ & $\begin{array}{c}\text { Maternal } \\
\text { Age } \\
\end{array}$ & $\begin{array}{c}\text { Ultasound } \\
\text { Abnorm. }\end{array}$ & $\begin{array}{c}\text { Fetal } \\
\text { Karyotype }\end{array}$ & $\begin{array}{c}\text { Risk with } \\
\text { Sonography }\end{array}$ & $\begin{array}{c}\text { Risk for } \\
\text { Trisomy } 21 \\
\end{array}$ & $\begin{array}{c}\text { Maternal } \\
\text { Age } \\
\end{array}$ & $\begin{array}{c}\text { Ultasound } \\
\text { Abnorm. }\end{array}$ & $\begin{array}{c}\text { Fetal } \\
\text { Karyotype } \\
\end{array}$ & $\begin{array}{c}\text { Risk with } \\
\text { Sonography }\end{array}$ \\
\hline 0.3333 & 34 & 0 & NORMAL & 0.2683065 & 0.001 & 34 & 0 & NORMAL & 0.00081 \\
\hline 0.25 & 34 & 0 & NORMAL & 0.20125 & 0.0013 & 19 & 0 & NORMAL & 0.00105 \\
\hline 0.1666 & 39 & 0 & NORMAL & 0.134113 & 0.0013 & 32 & 0 & NORMAL & \\
\hline 0.1 & 34 & 1 & NORMAL & 1.3697 & 0.0014 & 32 & 0 & NORMAL & 0.00113 \\
\hline 0.0909 & 38 & 0 & NORMAL & 0.0731745 & 0.0015 & 21 & 0 & NORMAL & 0.00121 \\
\hline 0.0833 & 34 & 0 & NORMAL & 0.0670565 & 0.0015 & 23 & 0 & NORMAL & \\
\hline 0.0714 & 34 & 0 & NORMAL & 0.057477 & 0.0015 & 28 & 0 & NORMAL & \\
\hline 0.067 & 47 & 1 & 18 & 0.917699 & 0.0015 & 32 & 0 & NORMAL & \\
\hline 0.0625 & 36 & 0 & NORMAL & 0.0503125 & 0.0015 & 33 & 0 & NORMAL & \\
\hline 0.0526 & 34 & 0 & NORMAL & 0.042343 & 0.0017 & 19 & 0 & NORMAL & 0.00137 \\
\hline 0.0526 & 38 & 0 & NORMAL & & 0.0017 & 22 & 0 & NORMAL & \\
\hline 0.0435 & 34 & 0 & NORMAL & 0.0350175 & 0.0017 & 26 & 0 & NORMAL & \\
\hline 0.037 & 34 & 0 & NORMAL & 0.029785 & 0.0017 & 29 & 0 & NORMAL & \\
\hline 0.037 & 34 & 0 & NORMAL & 0.029785 & 0.0017 & 30 & 0 & NORMAL & \\
\hline 0.0333 & 45 & 0 & NORMAL & 0.0268065 & 0.0017 & 33 & 0 & NORMAL & \\
\hline 0.0333 & 45 & 0 & NORMAL & & 0.0017 & 33 & 0 & NORMAL & \\
\hline 0.0333 & 45 & 0 & NORMAL & & 0.0018 & 30 & 0 & NORMAL & 0.00145 \\
\hline 0.0313 & 34 & 0 & NORMAL & 0.0251965 & 0.0021 & 20 & 0 & NORMAL & 0.00169 \\
\hline 0.0294 & 35 & 0 & NORMAL & 0.023667 & 0.0021 & 21 & 0 & NORMAL & \\
\hline 0.0278 & 34 & 0 & NORMAL & 0.022379 & 0.0021 & 23 & 0 & NORMAL & \\
\hline 0.0278 & 36 & 0 & NORMAL & & 0.0021 & 23 & 0 & NORMAL & \\
\hline 0.0263 & 34 & 0 & NORMAL & 0.0211715 & 0.0021 & 25 & 0 & NORMAL & \\
\hline 0.0263 & 44 & 0 & NORMAL & & 0.0021 & 25 & 0 & NORMAL & \\
\hline 0.0263 & 44 & 0 & NORMAL & & 0.0021 & 25 & 0 & NORMAL & \\
\hline 0.0263 & 44 & 0 & NORMAL & & 0.0021 & 27 & 0 & NORMAL & \\
\hline 0.0263 & 44 & 0 & NORMAL & & 0.0021 & 29 & 0 & NORMAL & \\
\hline 0.0263 & 44 & 0 & NORMAL & & 0.0021 & 29 & 0 & NORMAL & \\
\hline 0.0263 & 44 & 0 & NORMAL & & 0.0021 & 31 & 0 & NORMAL & \\
\hline 0.0263 & 45 & 0 & NORMAL & & 0.0021 & 32 & 0 & NORMAL & \\
\hline 0.0256 & 38 & 0 & NORMAL & 0.020608 & 0.0021 & 33 & 0 & NORMAL & \\
\hline 0.0217 & 36 & 0 & NORMAL & 0.0174685 & 0.0021 & 34 & 0 & NORMAL & \\
\hline 0.0204 & 39 & 0 & NORMAL & 0.016422 & 0.0021 & 34 & 0 & NORMAL & \\
\hline 0.0204 & 43 & 0 & NORMAL & & 0.0021 & 34 & 0 & NORMAL & \\
\hline 0.0204 & 43 & 0 & NORMAL & & 0.0021 & 34 & 0 & NORMAL & \\
\hline 0.0204 & 43 & 0 & NORMAL & & 0.0021 & 34 & 0 & NORMAL & \\
\hline 0.0204 & 43 & 0 & NORMAL & & 0.0021 & 34 & 0 & NORMAL & \\
\hline 0.0204 & 43 & 0 & NORMAL & & 0.0021 & 34 & 0 & NORMAL & \\
\hline 0.0204 & 43 & 0 & NORMAL & & 0.0021 & 34 & 0 & NORMAL & \\
\hline 0.0204 & 43 & 0 & NORMAL & & 0.0021 & 34 & 0 & NORMAL & \\
\hline 0.0204 & 43 & 0 & NORMAL & & 0.0021 & 34 & 0 & NORMAL & \\
\hline 0.0204 & 43 & 0 & NORMAL & & 0.0021 & 34 & 0 & NORMAL & \\
\hline
\end{tabular}




\begin{tabular}{|c|c|c|c|c|c|c|c|c|}
\hline 0.0204 & 43 & 0 & NORMAL & & 0.0021 & 34 & 0 & NORMAL \\
\hline 0.0204 & 43 & 0 & NORMAL & & 0.0021 & 34 & 0 & NORMAL \\
\hline 0.02 & 34 & 0 & NORMAL & 0.0161 & 0.0021 & 34 & 0 & NORM \\
\hline 0.0196 & 34 & 0 & NORMAL & 0.015778 & 0.0021 & 34 & 0 & NORM \\
\hline 0.0175 & 35 & 0 & NORMAL & 0.0140875 & 0.0021 & 34 & 0 & NORM \\
\hline 0.0167 & 35 & 0 & NORMAL & 0.0134435 & 0.0021 & 34 & 1 & NORM \\
\hline 0.0161 & 34 & 0 & NORMAL & 0.0129605 & 0.0021 & 34 & 0 & NORM \\
\hline 0.0161 & 34 & 0 & NORMAL & & 0.0021 & 34 & 0 & NORM \\
\hline 0.0159 & 42 & 0 & NORMAL & 0.0127995 & 0.0021 & 34 & 0 & NORM \\
\hline 0.0159 & 42 & 1 & NORMAL & 0.2177823 & 0.0021 & 34 & 0 & NORM \\
\hline 0.0159 & 42 & 1 & NORMAL & & 0.0021 & 34 & 0 & NORM \\
\hline 0.0159 & 42 & 0 & NORMAL & & 0.0021 & 34 & 0 & NORN \\
\hline 0.0159 & 42 & 0 & NORMAL & & 0.0021 & 34 & 0 & NORM \\
\hline 0.0159 & 42 & 0 & NORMAL & & 0.0021 & 34 & 0 & NORM \\
\hline 0.0159 & 42 & 0 & NORMAL & & 0.0021 & 34 & 0 & NORM \\
\hline 0.0159 & 42 & 0 & NORMAL & & 0.0021 & 34 & 0 & NORN \\
\hline 0.0159 & 42 & 0 & NORMAL & & 0.0021 & 34 & 0 & NORN \\
\hline 0.0159 & 42 & 0 & NORMAL & & 0.0021 & 34 & 0 & NORN \\
\hline 0.0159 & 42 & 0 & NORMAL & & 0.0021 & 34 & 0 & NORM \\
\hline 0.0159 & 42 & 0 & NORMAL & & 0.0021 & 34 & 0 & NORN \\
\hline 0.0159 & 42 & 0 & NORMAL & & 0.0021 & 34 & 0 & NORM \\
\hline 0.0159 & 42 & 0 & NORMAL & & 0.0021 & 34 & 0 & NORM \\
\hline 0.0159 & 42 & 0 & NORMAL & & 0.0021 & 34 & 0 & NORM \\
\hline 0.0159 & 42 & 0 & NORMAL & & 0.0021 & 34 & 0 & NORM \\
\hline 0.0159 & 42 & 0 & 18 & 0.0127995 & 0.0021 & 34 & 0 & NORM \\
\hline 0.0159 & 42 & 0 & NORMAL & & 0.0021 & 34 & 0 & NORM \\
\hline 0.0159 & 42 & 2 & 18 & 0.2177823 & 0.0021 & 34 & 0 & NORMA \\
\hline 0.0159 & 42 & 2 & NORMAL & & 0.0021 & 34 & 0 & NORM \\
\hline 0.0159 & 42 & 0 & NORMAL & & 0.0021 & 34 & 0 & NORM \\
\hline 0.0159 & 42 & 0 & NORMAL & & 0.0021 & 34 & 0 & NORM \\
\hline 0.0159 & 42 & 0 & NORMAL & & 0.0021 & 34 & 0 & NORM \\
\hline 0.0159 & 42 & 0 & NORMAL & & 0.0021 & 34 & 0 & NORM \\
\hline 0.0159 & 42 & 0 & NORMAL & & 0.0021 & 34 & 0 & NORM \\
\hline 0.0145 & 37 & 0 & NORMAL & 0.0116725 & 0.0021 & 34 & 0 & NORM \\
\hline 0.0133 & 35 & 0 & NORMAL & 0.0107065 & 0.0021 & 34 & 0 & NORM \\
\hline 0.0123 & 35 & 0 & NORMAL & 0.0099015 & 0.0021 & 34 & 0 & NORMA \\
\hline 0.0123 & 36 & 0 & NORMAL & & 0.0021 & 34 & 0 & NORM \\
\hline 0.0123 & 36 & 0 & NORMAL & & 0.0021 & 34 & 0 & NORM \\
\hline 0.0122 & 41 & 0 & NORMAL & 0.009821 & 0.0021 & 34 & 0 & NORM \\
\hline 0.0122 & 41 & 0 & NORMAL & & 0.0021 & 34 & 0 & NORM \\
\hline 0.0122 & 41 & 1 & NORMAL & 0.1671034 & 0.0021 & 34 & 0 & NORM \\
\hline 0.0122 & 41 & 0 & NORMAL & & 0.0021 & 34 & 0 & NORM \\
\hline 0.0122 & 41 & 0 & NORMAL & & 0.0021 & 34 & 0 & NORM \\
\hline 0.0122 & 41 & 0 & NORMAL & & 0.0021 & 34 & 0 & NORMAL \\
\hline 0.0122 & 41 & 0 & NORMAL & & 0.0021 & 34 & 0 & NORM \\
\hline 0.0122 & 41 & 0 & NORMAL & & 0.0021 & 34 & 0 & NORMA \\
\hline 0.0122 & 41 & 0 & NORMAL & & 0.0021 & 34 & 0 & NORM \\
\hline
\end{tabular}




\begin{tabular}{|c|c|c|c|c|c|c|c|c|c|}
\hline 0.0122 & 41 & 1 & NORMAL & & 0.0021 & 34 & 0 & NORMAL & \\
\hline 0.0122 & 41 & 0 & NORMAL & & 0.0021 & 34 & 0 & NORMAL & \\
\hline 0.0122 & 41 & 0 & NORMAL & & 0.0021 & 34 & 0 & NORMAL & \\
\hline 0.0122 & 41 & 1 & NORMAL & & 0.0021 & 34 & 0 & NORMAL & \\
\hline 0.0122 & 41 & 0 & NORMAL & & 0.0021 & 34 & 0 & NORMAL & \\
\hline 0.0122 & 41 & 0 & NORMAL & & 0.0021 & 34 & 0 & NORMAL & \\
\hline 0.0122 & 41 & 0 & NORMAL & & 0.0021 & 34 & 0 & NORMAL & \\
\hline 0.0122 & 41 & 0 & NORMAL & & 0.0023 & 19 & 0 & NORMAL & 0.00185 \\
\hline 0.0122 & 41 & 0 & NORMAL & & 0.0023 & 20 & 0 & NORMAL & \\
\hline 0.0122 & 41 & 0 & NORMAL & & 0.0023 & 22 & 0 & NORMAL & \\
\hline 0.0122 & 41 & 0 & NORMAL & & 0.0024 & 20 & 0 & NORMAL & 0.00193 \\
\hline 0.0122 & 41 & 0 & NORMAL & & 0.0024 & 21 & 0 & NORMAL & \\
\hline 0.0122 & 41 & 0 & NORMAL & & 0.0024 & 29 & 0 & NORMAL & \\
\hline 0.0122 & 41 & 0 & NORMAL & & 0.0024 & 32 & 0 & NORMAL & \\
\hline 0.0122 & 41 & 0 & NORMAL & & 0.0025 & 28 & 0 & NORMAL & 0.00201 \\
\hline 0.0122 & 41 & 0 & NORMAL & & 0.0025 & 28 & 0 & NORMAL & \\
\hline 0.0122 & 41 & 0 & NORMAL & & 0.0025 & 32 & 0 & NORMAL & \\
\hline 0.0122 & 41 & 0 & NORMAL & & 0.0025 & 34 & 0 & NORMAL & \\
\hline 0.0122 & 41 & 0 & NORMAL & & 0.0026 & 31 & 0 & NORMAL & 0.00209 \\
\hline 0.0122 & 41 & 1 & NORMAL & & 0.0027 & 18 & 0 & NORMAL & 0.00217 \\
\hline 0.0122 & 41 & 0 & NORMAL & & 0.0027 & 19 & 0 & NORMAL & \\
\hline 0.0122 & 41 & 0 & NORMAL & & 0.0027 & 19 & 0 & NORMAL & \\
\hline 0.0122 & 41 & 0 & NORMAL & & 0.0027 & 20 & 0 & NORMAL & \\
\hline 0.0122 & 41 & 0 & NORMAL & & 0.0027 & 20 & 0 & NORMAL & \\
\hline 0.0122 & 41 & 0 & NORMAL & & 0.0027 & 21 & 0 & NORMAL & \\
\hline 0.0122 & 41 & 0 & $x$ & & 0.0027 & 22 & 0 & NORMAL & \\
\hline 0.0122 & 41 & 0 & NORMAL & & 0.0027 & 22 & 0 & NORMAL & \\
\hline 0.0122 & 41 & 0 & NORMAL & & 0.0027 & 22 & 0 & NORMAL & \\
\hline 0.0122 & 41 & 0 & NORMAL & & 0.0027 & 22 & 0 & NORMAL & \\
\hline 0.0122 & 41 & 0 & NORMAL & & 0.0027 & 22 & 0 & NORMAL & \\
\hline 0.0122 & 41 & 0 & NORMAL & & 0.0027 & 22 & 0 & NORMAL & \\
\hline 0.0122 & 41 & 0 & NORMAL & & 0.0027 & 23 & 0 & NORMAL & \\
\hline 0.0122 & 41 & 0 & NORMAL & & 0.0027 & 23 & 0 & NORMAL & \\
\hline 0.0122 & 41 & 0 & NORMAL & & 0.0027 & 23 & 0 & NORMAL & \\
\hline 0.0122 & 41 & 0 & NORMAL & & 0.0027 & 24 & 0 & NORMAL & \\
\hline 0.0103 & 36 & 0 & NORMAL & 0.0082915 & 0.0027 & 24 & 0 & NORMAL & \\
\hline 0.01 & 38 & 0 & NORMAL & 0.00805 & 0.0027 & 24 & 0 & NORMAL & \\
\hline 0.0095 & 35 & 0 & NORMAL & 0.0076475 & 0.0027 & 24 & 0 & NORMAL & \\
\hline 0.0094 & 40 & 0 & NORMAL & 0.007567 & 0.0027 & 24 & 0 & NORMAL & \\
\hline 0.0094 & 40 & 0 & NORMAL & & 0.0027 & 24 & 0 & NORMAL & \\
\hline 0.0094 & 40 & 0 & NORMAL & & 0.0027 & 25 & 0 & NORMAL & \\
\hline 0.0094 & 40 & 0 & NORMAL & & 0.0027 & 25 & 0 & NORMAL & \\
\hline 0.0094 & 40 & 0 & NORMAL & & 0.0027 & 25 & 0 & NORMAL & \\
\hline 0.0094 & 40 & 0 & NORMAL & & 0.0027 & 26 & 0 & NORMAL & \\
\hline 0.0094 & 40 & 0 & NORMAL & & 0.0027 & 26 & 0 & NORMAL & \\
\hline 0.0094 & 40 & 0 & NORMAL & & 0.0027 & 26 & 0 & NORMAL & \\
\hline 0.0094 & 40 & 0 & NORMAL & & 0.0027 & 26 & 0 & NORMAL & \\
\hline
\end{tabular}




\begin{tabular}{|c|c|c|c|c|c|c|c|c|c|}
\hline 0.0094 & 40 & 0 & NORMAL & & 0.0027 & 27 & 0 & NORMAL & \\
\hline 0.0094 & 40 & 0 & NORMAL & & 0.0027 & 27 & 0 & NORMAL & \\
\hline 0.0094 & 40 & 0 & NORMAL & & 0.0027 & 27 & 0 & NORMAL & \\
\hline 0.0094 & 40 & 0 & NORMAL & & 0.0027 & 27 & 0 & NORMAL & \\
\hline 0.0094 & 40 & 0 & NORMAL & & 0.0027 & 27 & 0 & NORMAL & \\
\hline 0.0094 & 40 & 0 & NORMAL & & 0.0027 & 27 & 0 & NORMAL & \\
\hline 0.0094 & 40 & 0 & NORMAL & & 0.0027 & 27 & 0 & NORMAL & \\
\hline 0.0094 & 40 & 0 & NORMAL & & 0.0027 & 27 & 0 & NORMAL & \\
\hline 0.0094 & 40 & 0 & NORMAL & & 0.0027 & 27 & 0 & NORMAL & \\
\hline 0.0094 & 40 & 0 & NORMAL & & 0.0027 & 27 & 0 & NORMAL & \\
\hline 0.0094 & 40 & 0 & NORMAL & & 0.0027 & 27 & 0 & NORMAL & \\
\hline 0.0094 & 40 & 0 & NORMAL & & 0.0027 & 28 & 0 & NORMAL & \\
\hline 0.0094 & 40 & 0 & NORMAL & & 0.0027 & 28 & 0 & NORMAL & \\
\hline 0.0094 & 40 & 0 & NORMAL & & 0.0027 & 28 & 0 & NORMAL & \\
\hline 0.0094 & 40 & 0 & NORMAL & & 0.0027 & 28 & 0 & NORMAL & \\
\hline 0.0094 & 40 & 0 & NORMAL & & 0.0027 & 29 & 0 & NORMAL & \\
\hline 0.0094 & 40 & 0 & NORMAL & & 0.0027 & 29 & 0 & NORMAL & \\
\hline 0.0094 & 40 & 0 & NORMAL & & 0.0027 & 29 & 0 & NORMAL & \\
\hline 0.0094 & 40 & 0 & NORMAL & & 0.0027 & 29 & 0 & NORMAL & \\
\hline 0.0094 & 40 & 0 & NORMAL & & 0.0027 & 30 & 0 & NORMAL & \\
\hline 0.0094 & 40 & 0 & NORMAL & & 0.0027 & 30 & 0 & NORMAL & \\
\hline 0.0094 & 40 & 0 & NORMAL & & 0.0027 & 30 & 0 & NORMAL & \\
\hline 0.0094 & 40 & 0 & NORMAL & & 0.0027 & 30 & 0 & NORMAL & \\
\hline 0.0094 & 40 & 0 & NORMAL & & 0.0027 & 31 & 0 & NORMAL & \\
\hline 0.0094 & 40 & 0 & NORMAL & & 0.0027 & 31 & 0 & NORMAL & \\
\hline 0.0094 & 40 & 0 & NORMAL & & 0.0027 & 32 & 0 & NORMAL & \\
\hline 0.0094 & 40 & 0 & NORMAL & & 0.0027 & 32 & 0 & NORMAL & \\
\hline 0.0094 & 40 & 0 & NORMAL & & 0.0027 & 32 & 0 & NORMAL & \\
\hline 0.0094 & 40 & 0 & NORMAL & & 0.0027 & 32 & 0 & NORMAL & \\
\hline 0.0094 & 40 & 0 & NORMAL & & 0.0027 & 32 & 0 & NORMAL & \\
\hline 0.0094 & 40 & 0 & NORMAL & & 0.0027 & 32 & 0 & NORMAL & \\
\hline 0.0094 & 40 & 0 & NORMAL & & 0.0027 & 32 & 0 & NORMAL & \\
\hline 0.0094 & 40 & 0 & NORMAL & & 0.0027 & 32 & 0 & NORMAL & \\
\hline 0.0094 & 40 & 0 & NORMAL & & 0.0027 & 33 & 0 & NORMAL & \\
\hline 0.0094 & 40 & 0 & NORMAL & & 0.0027 & 33 & 0 & NORMAL & \\
\hline 0.0094 & 40 & 0 & NORMAL & & 0.0027 & 33 & 0 & NORMAL & \\
\hline 0.0094 & 40 & 0 & NORMAL & & 0.0027 & 34 & 0 & NORMAL & \\
\hline 0.0094 & 40 & 0 & NORMAL & & 0.0027 & 34 & 0 & NORMAL & \\
\hline 0.0094 & 40 & 0 & NORMAL & & 0.0027 & 34 & 0 & NORMAL & \\
\hline 0.0094 & 40 & 1 & NORMAL & 0.1287518 & 0.0028 & 21 & 0 & NORMAL & 0.00225 \\
\hline 0.0094 & 40 & 0 & NORMAL & & 0.0028 & 28 & 0 & NORMAL & \\
\hline 0.0094 & 40 & 0 & NORMAL & & 0.0029 & 20 & 0 & NORMAL & 0.00233 \\
\hline 0.0094 & 40 & 0 & NORMAL & & 0.0029 & 23 & 0 & NORMAL & \\
\hline 0.0094 & 40 & 0 & NORMAL & & 0.0029 & 24 & 0 & NORMAL & \\
\hline 0.0094 & 40 & 0 & NORMAL & & 0.003 & 20 & 0 & NORMAL & 0.00242 \\
\hline 0.0094 & 40 & 0 & NORMAL & & 0.003 & 21 & 0 & NORMAL & \\
\hline 0.0094 & 40 & 0 & NORMAL & & 0.003 & 22 & 1 & NORMAL & 0.04109 \\
\hline
\end{tabular}




\begin{tabular}{|c|c|c|c|c|c|c|c|c|c|}
\hline 0.0094 & 40 & 0 & NORMAL & & 0.0031 & 13 & 0 & NORMAL & 0.00250 \\
\hline 0.0094 & 40 & 0 & NORMAL & & 0.0031 & 16 & 0 & NORMAL & \\
\hline 0.0094 & 40 & 1 & 21 & 0.1287518 & 0.0031 & 20 & 0 & NORMAL & \\
\hline 0.0074 & 35 & 0 & NORMAL & 0.005957 & 0.0031 & 26 & 0 & NORMAL & \\
\hline 0.0074 & 37 & 0 & 18 & 0.005957 & 0.0031 & 26 & 0 & NORMAL & \\
\hline 0.0074 & 37 & 0 & NORMAL & & 0.0031 & 27 & 0 & NORMAL & \\
\hline 0.0074 & 37 & 0 & NORMAL & & 0.0031 & 28 & 0 & NORMAL & \\
\hline 0.0074 & 39 & 0 & NORMAL & & 0.0031 & 30 & 0 & NORMAL & \\
\hline 0.0074 & 39 & 0 & NORMAL & & 0.0031 & 30 & 0 & NORMAL & \\
\hline 0.0074 & 39 & 0 & NORMAL & & 0.0031 & 32 & 0 & NORMAL & \\
\hline 0.0074 & 39 & 0 & NORMAL & & 0.0031 & 32 & 0 & NORMAL & \\
\hline 0.0074 & 39 & 0 & NORMAL & & 0.0031 & 34 & 0 & NORMAL & \\
\hline 0.0074 & 39 & 0 & NORMAL & & 0.0031 & 34 & 0 & NORMAL & \\
\hline 0.0074 & 39 & 1 & NORMAL & 0.1013578 & 0.0031 & 34 & 0 & NORMAL & \\
\hline 0.0074 & 39 & 0 & NORMAL & & 0.0032 & 21 & 0 & NORMAL & 0.00578 \\
\hline 0.0074 & 39 & 0 & NORMAL & & 0.0032 & 21 & 0 & NORMAL & \\
\hline 0.0074 & 39 & 0 & NORMAL & & 0.0032 & 26 & 1 & NORMAL & 0.04383 \\
\hline 0.0074 & 39 & 0 & NORMAL & & 0.0032 & 28 & 1 & NORMAL & \\
\hline 0.0074 & 39 & 0 & NORMAL & & 0.0032 & 29 & 0 & NORMAL & \\
\hline 0.0074 & 39 & 0 & NORMAL & & 0.0032 & 33 & 0 & NORMAL & \\
\hline 0.0074 & 39 & 0 & NORMAL & & 0.0032 & 34 & 0 & NORMAL & \\
\hline 0.0074 & 39 & 1 & NORMAL & 0.1013578 & 0.0032 & 34 & 0 & NORMAL & \\
\hline 0.0074 & 39 & 0 & NORMAL & & 0.0032 & 34 & 0 & NORMAL & \\
\hline 0.0074 & 39 & 0 & NORMAL & & 0.0033 & 17 & 0 & NORMAL & 0.00266 \\
\hline 0.0074 & 39 & 0 & NORMAL & & 0.0033 & 18 & 0 & NORMAL & \\
\hline 0.0074 & 39 & 0 & NORMAL & & 0.0033 & 19 & 0 & NORMAL & \\
\hline 0.0074 & 39 & 1 & NORMAL & & 0.0033 & 20 & 0 & NORMAL & \\
\hline 0.0074 & 39 & 0 & NORMAL & & 0.0033 & 20 & 0 & NORMAL & \\
\hline 0.0074 & 39 & 0 & NORMAL & & 0.0033 & 21 & 0 & NORMAL & \\
\hline 0.0074 & 39 & 0 & NORMAL & & 0.0033 & 21 & 0 & NORMAL & \\
\hline 0.0074 & 39 & 0 & NORMAL & & 0.0033 & 23 & 0 & NORMAL & \\
\hline 0.0074 & 39 & 0 & NORMAL & & 0.0033 & 24 & 0 & NORMAL & \\
\hline 0.0074 & 39 & 0 & NORMAL & & 0.0033 & 24 & 0 & NORMAL & \\
\hline 0.0074 & 39 & 0 & NORMAL & & 0.0033 & 24 & 0 & NORMAL & \\
\hline 0.0074 & 39 & 0 & NORMAL & & 0.0033 & 24 & 0 & NORMAL & \\
\hline 0.0074 & 39 & 0 & NORMAL & & 0.0033 & 24 & 0 & NORMAL & \\
\hline 0.0074 & 39 & 0 & NORMAL & & 0.0033 & 25 & 0 & NORMAL & \\
\hline 0.0074 & 39 & 0 & NORMAL & & 0.0033 & 26 & 0 & NORMAL & \\
\hline 0.0074 & 39 & 0 & NORMAL & & 0.0033 & 26 & 0 & NORMAL & \\
\hline 0.0074 & 39 & 0 & NORMAL & & 0.0033 & 26 & 0 & NORMAL & \\
\hline 0.0074 & 39 & 0 & NORMAL & & 0.0033 & 26 & 0 & NORMAL & \\
\hline 0.0074 & 39 & 0 & NORMAL & & 0.0033 & 26 & 0 & NORMAL & \\
\hline 0.0074 & 39 & 0 & NORMAL & & 0.0033 & 27 & 0 & NORMAL & \\
\hline 0.0074 & 39 & 0 & NORMAL & & 0.0033 & 28 & 0 & NORMAL & \\
\hline 0.0074 & 39 & 0 & NORMAL & & 0.0033 & 30 & 0 & NORMAL & \\
\hline 0.0074 & 39 & 0 & NORMAL & & 0.0033 & 31 & 0 & NORMAL & \\
\hline 0.0074 & 39 & 0 & NORMAL & & 0.0033 & 31 & 0 & NORMAL & \\
\hline
\end{tabular}




\begin{tabular}{|c|c|c|c|c|c|c|c|c|c|}
\hline 0.0074 & 39 & 0 & NORMAL & & 0.0033 & 33 & 0 & NORMAL & \\
\hline 0.0074 & 39 & 0 & NORMAL & & 0.0033 & 33 & 0 & NORMAL & \\
\hline 0.0074 & 39 & 0 & NORMAL & & 0.0033 & 34 & 0 & NORMAL & \\
\hline 0.0074 & 39 & 0 & NORMAL & & 0.0033 & 34 & 0 & NORMAL & \\
\hline 0.0074 & 39 & 0 & NORMAL & & 0.0034 & 19 & 0 & NORMAL & 0.00274 \\
\hline 0.0074 & 39 & 0 & NORMAL & & 0.0034 & 19 & 0 & NORMAL & \\
\hline 0.0074 & 39 & 0 & NORMAL & & 0.0034 & 21 & 0 & NORMAL & \\
\hline 0.0074 & 39 & 0 & NORMAL & & 0.0034 & 21 & 0 & NORMAL & \\
\hline 0.0074 & 39 & 0 & NORMAL & & 0.0034 & 23 & 0 & NORMAL & \\
\hline 0.0074 & 39 & 0 & NORMAL & & 0.0034 & 25 & 0 & NORMAL & \\
\hline 0.0074 & 39 & 0 & NORMAL & & 0.0034 & 25 & 0 & NORMAL & \\
\hline 0.0074 & 39 & 0 & NORMAL & & 0.0034 & 25 & 0 & NORMAL & \\
\hline 0.0074 & 39 & 0 & NORMAL & & 0.0034 & 25 & 0 & NORMAL & \\
\hline 0.0074 & 39 & 1 & NORMAL & & 0.0034 & 27 & 0 & NORMAL & \\
\hline 0.0074 & 39 & 0 & NORMAL & & 0.0034 & 28 & 0 & NORMAL & \\
\hline 0.0074 & 39 & 0 & NORMAL & & 0.0034 & 28 & 0 & NORMAL & \\
\hline 0.0074 & 39 & 0 & NORMAL & & 0.0034 & 32 & 0 & NORMAL & \\
\hline 0.0074 & 39 & 0 & NORMAL & & 0.0034 & 32 & 0 & NORMAL & \\
\hline 0.0074 & 39 & 0 & NORMAL & & 0.0034 & 33 & 0 & NORMAL & \\
\hline 0.0074 & 39 & 0 & NORMAL & & 0.0035 & 15 & 0 & NORMAL & 0.00282 \\
\hline 0.0074 & 39 & 0 & NORMAL & & 0.0035 & 18 & 0 & NORMAL & \\
\hline 0.0074 & 39 & 0 & NORMAL & & 0.0035 & 20 & 0 & NORMAL & \\
\hline 0.0074 & 39 & 0 & NORMAL & & 0.0035 & 21 & 0 & NORMAL & \\
\hline 0.0074 & 39 & 0 & NORMAL & & 0.0035 & 22 & 0 & NORMAL & \\
\hline 0.0074 & 39 & 0 & NORMAL & & 0.0035 & 22 & 0 & NORMAL & \\
\hline 0.0074 & 39 & 0 & NORMAL & & 0.0035 & 22 & 0 & NORMAL & \\
\hline 0.0074 & 39 & 0 & NORMAL & & 0.0035 & 23 & 0 & NORMAL & \\
\hline 0.0074 & 39 & 0 & NORMAL & & 0.0035 & 24 & 0 & NORMAL & \\
\hline 0.0074 & 39 & 0 & NORMAL & & 0.0035 & 24 & 0 & NORMAL & \\
\hline 0.0074 & 39 & 0 & NORMAL & & 0.0035 & 25 & 0 & NORMAL & \\
\hline 0.0074 & 39 & 0 & NORMAL & & 0.0035 & 25 & 0 & NORMAL & \\
\hline 0.0074 & 39 & 0 & NORMAL & & 0.0035 & 25 & 0 & NORMAL & \\
\hline 0.0074 & 39 & 0 & NORMAL & & 0.0035 & 25 & 0 & NORMAL & \\
\hline 0.0074 & 39 & 0 & NORMAL & & 0.0035 & 26 & 0 & NORMAL & \\
\hline 0.0074 & 39 & 0 & NORMAL & & 0.0035 & 26 & 0 & NORMAL & \\
\hline 0.0074 & 39 & 0 & NORMAL & & 0.0035 & 26 & 0 & NORMAL & \\
\hline 0.0074 & 39 & 0 & 21 & 0.005957 & 0.0035 & 26 & 0 & NORMAL & \\
\hline 0.0074 & 39 & 0 & NORMAL & & 0.0035 & 27 & 0 & NORMAL & \\
\hline 0.0074 & 39 & 0 & NORMAL & & 0.0035 & 27 & 0 & NORMAL & \\
\hline 0.0074 & 39 & 0 & NORMAL & & 0.0035 & 27 & 0 & NORMAL & \\
\hline 0.0074 & 39 & 0 & NORMAL & & 0.0035 & 29 & 0 & NORMAL & \\
\hline 0.0074 & 39 & 0 & NORMAL & & 0.0035 & 29 & 0 & NORMAL & \\
\hline 0.0074 & 39 & 0 & NORMAL & & 0.0035 & 29 & 0 & NORMAL & \\
\hline 0.0074 & 39 & 0 & NORMAL & & 0.0035 & 29 & 0 & NORMAL & \\
\hline 0.0074 & 39 & 0 & NORMAL & & 0.0035 & 29 & 0 & NORMAL & \\
\hline 0.0074 & 39 & 0 & NORMAL & & 0.0035 & 30 & 0 & NORMAL & \\
\hline 0.0074 & 39 & 0 & NORMAL & & 0.0035 & 30 & 0 & NORMAL & \\
\hline
\end{tabular}




\begin{tabular}{|c|c|c|c|c|c|c|c|c|c|}
\hline 0.0074 & 39 & 1 & NORMAL & & 0.0035 & 30 & 0 & NORMAL & \\
\hline 0.0074 & 39 & 0 & NORMAL & & 0.0035 & 30 & 0 & NORMAL & \\
\hline 0.0074 & 39 & 0 & NORMAL & & 0.0035 & 30 & 0 & NORMAL & \\
\hline 0.0074 & 39 & 0 & NORMAL & & 0.0035 & 32 & 0 & NORMAL & \\
\hline 0.0074 & 39 & 0 & NORMAL & & 0.0035 & 32 & 0 & NORMAL & \\
\hline 0.0074 & 39 & 0 & NORMAL & & 0.0035 & 32 & 0 & NORMAL & \\
\hline 0.0074 & 39 & 0 & NORMAL & & 0.0035 & 32 & 0 & NORMAL & \\
\hline 0.0074 & 39 & 0 & NORMAL & & 0.0035 & 33 & 0 & NORMAL & \\
\hline 0.0074 & 39 & 0 & NORMAL & & 0.0035 & 33 & 0 & NORMAL & \\
\hline 0.0074 & 39 & 0 & NORMAL & & 0.0035 & 33 & 0 & NORMAL & \\
\hline 0.007 & 39 & 0 & NORMAL & 0.005635 & 0.0035 & 33 & 0 & NORMAL & \\
\hline 0.0058 & 35 & 0 & NORMAL & 0.004669 & 0.0035 & 34 & 0 & NORMAL & \\
\hline 0.0057 & 38 & 0 & NORMAL & 0.0045885 & 0.0035 & 34 & 0 & NORMAL & \\
\hline 0.0057 & 38 & 0 & NORMAL & & 0.0035 & 34 & 0 & NORMAL & \\
\hline 0.0057 & 38 & 0 & NORMAL & & 0.0035 & 34 & 0 & NORMAL & \\
\hline 0.0057 & 38 & 0 & NORMAL & & 0.0036 & 17 & 0 & NORMAL & 0.00290 \\
\hline 0.0057 & 38 & 0 & NORMAL & & 0.0036 & 18 & 0 & NORMAL & \\
\hline 0.0057 & 38 & 0 & NORMAL & & 0.0036 & 18 & 0 & NORMAL & \\
\hline 0.0057 & 38 & 0 & NORMAL & & 0.0036 & 20 & 0 & NORMAL & \\
\hline 0.0057 & 38 & 0 & NORMAL & & 0.0036 & 24 & 0 & NORMAL & \\
\hline 0.0057 & 38 & 0 & NORMAL & & 0.0036 & 27 & 0 & NORMAL & \\
\hline 0.0057 & 38 & 0 & NORMAL & & 0.0036 & 29 & 0 & NORMAL & \\
\hline 0.0057 & 38 & 0 & NORMAL & & 0.0036 & 33 & 0 & NORMAL & \\
\hline 0.0057 & 38 & 0 & NORMAL & & 0.0036 & 33 & 0 & NORMAL & \\
\hline 0.0057 & 38 & 0 & NORMAL & & 0.0036 & 33 & 0 & NORMAL & \\
\hline 0.0057 & 38 & 0 & NORMAL & & 0.0037 & 18 & 0 & NORMAL & 0.00298 \\
\hline 0.0057 & 38 & 0 & NORMAL & & 0.0037 & 20 & 0 & NORMAL & \\
\hline 0.0057 & 38 & 0 & NORMAL & & 0.0037 & 21 & 0 & NORMAL & \\
\hline 0.0057 & 38 & 0 & NORMAL & & 0.0037 & 21 & 0 & NORMAL & \\
\hline 0.0057 & 38 & 0 & NORMAL & & 0.0037 & 27 & 0 & NORMAL & \\
\hline 0.0057 & 38 & 0 & NORMAL & & 0.0037 & 27 & 0 & NORMAL & \\
\hline 0.0057 & 38 & 0 & NORMAL & & 0.0037 & 28 & 0 & NORMAL & \\
\hline 0.0057 & 38 & 1 & NORMAL & 0.0780729 & 0.0037 & 29 & 0 & NORMAL & \\
\hline 0.0057 & 38 & 0 & NORMAL & & 0.0037 & 29 & 0 & NORMAL & \\
\hline 0.0057 & 38 & 0 & NORMAL & & 0.0037 & 30 & 0 & NORMAL & \\
\hline 0.0057 & 38 & 0 & NORMAL & & 0.0037 & 33 & 0 & NORMAL & \\
\hline 0.0057 & 38 & 0 & NORMAL & & 0.0037 & 33 & 0 & NORMAL & \\
\hline 0.0057 & 38 & 0 & NORMAL & & 0.0037 & 34 & 0 & NORMAL & \\
\hline 0.0057 & 38 & 0 & NORMAL & & 0.0038 & 25 & 0 & NORMAL & 0.00306 \\
\hline 0.0057 & 38 & 0 & NORMAL & & 0.0038 & 28 & 0 & NORMAL & \\
\hline 0.0057 & 38 & 0 & NORMAL & & 0.0038 & 31 & 0 & NORMAL & \\
\hline 0.0057 & 38 & 0 & NORMAL & & 0.0038 & 32 & 0 & NORMAL & \\
\hline 0.0057 & 38 & 0 & NORMAL & & 0.0038 & 32 & 0 & NORMAL & \\
\hline 0.0057 & 38 & 0 & NORMAL & & 0.0038 & 33 & 0 & NORMAL & \\
\hline 0.0057 & 38 & 0 & NORMAL & & 0.0038 & 34 & 0 & NORMAL & \\
\hline 0.0057 & 38 & 0 & NORMAL & & 0.0039 & 16 & 0 & NORMAL & 0.00314 \\
\hline 0.0057 & 38 & 0 & NORMAL & & 0.0039 & 17 & 0 & NORMAL & \\
\hline
\end{tabular}




\begin{tabular}{|c|c|c|c|c|c|c|c|c|c|}
\hline 0.0057 & 38 & 0 & NORMAL & & 0.0039 & 23 & 0 & NORMAL & \\
\hline 0.0057 & 38 & 0 & NORMAL & & 0.0039 & 24 & 0 & NORMAL & \\
\hline 0.0057 & 38 & 0 & NORMAL & & 0.0039 & 25 & 0 & NORMAL & \\
\hline 0.0057 & 38 & 0 & NORMAL & & 0.0039 & 25 & 0 & NORMAL & \\
\hline 0.0057 & 38 & 0 & NORMAL & & 0.0039 & 27 & 0 & NORMAL & \\
\hline 0.0057 & 38 & 0 & NORMAL & & 0.0039 & 28 & 0 & NORMAL & \\
\hline 0.0057 & 38 & 0 & NORMAL & & 0.0039 & 29 & 0 & NORMAL & \\
\hline 0.0057 & 38 & 0 & NORMAL & & 0.0039 & 30 & 0 & NORMAL & \\
\hline 0.0057 & 38 & 0 & NORMAL & & 0.0039 & 33 & 0 & NORMAL & \\
\hline 0.0057 & 38 & 0 & NORMAL & & 0.0039 & 33 & 0 & NORMAL & \\
\hline 0.0057 & 38 & 0 & NORMAL & & 0.004 & 18 & 0 & NORMAL & 0.00322 \\
\hline 0.0057 & 38 & 0 & NORMAL & & 0.004 & 18 & 0 & NORMAL & \\
\hline 0.0057 & 38 & 0 & NORMAL & & 0.004 & 18 & 0 & NORMAL & \\
\hline 0.0057 & 38 & 0 & NORMAL & & 0.004 & 18 & 0 & NORMAL & \\
\hline 0.0057 & 38 & 0 & NORMAL & & 0.004 & 18 & 0 & NORMAL & \\
\hline 0.0057 & 38 & 0 & NORMAL & & 0.004 & 18 & 0 & NORMAL & \\
\hline 0.0057 & 38 & 0 & NORMAL & & 0.004 & 19 & 0 & NORMAL & \\
\hline 0.0057 & 38 & 0 & NORMAL & & 0.004 & 19 & 0 & NORMAL & \\
\hline 0.0057 & 38 & 0 & NORMAL & & 0.004 & 19 & 0 & NORMAL & \\
\hline 0.0057 & 38 & 0 & NORMAL & & 0.004 & 19 & 0 & NORMAL & \\
\hline 0.0057 & 38 & 0 & NORMAL & & 0.004 & 19 & 0 & NORMAL & \\
\hline 0.0057 & 38 & 0 & NORMAL & & 0.004 & 20 & 0 & NORMAL & \\
\hline 0.0057 & 38 & 0 & NORMAL & & 0.004 & 22 & 0 & NORMAL & \\
\hline 0.0057 & 38 & 0 & NORMAL & & 0.004 & 23 & 0 & NORMAL & \\
\hline 0.0057 & 38 & 0 & NORMAL & & 0.004 & 23 & 2 & NORMAL & 0.05479 \\
\hline 0.0057 & 38 & 0 & NORMAL & & 0.004 & 24 & 0 & NORMAL & \\
\hline 0.0057 & 38 & 0 & NORMAL & & 0.004 & 25 & 0 & NORMAL & \\
\hline 0.0057 & 38 & 0 & NORMAL & & 0.004 & 28 & 0 & NORMAL & \\
\hline 0.0057 & 38 & 0 & NORMAL & & 0.004 & 28 & 0 & NORMAL & \\
\hline 0.0057 & 38 & 0 & NORMAL & & 0.004 & 29 & 0 & NORMAL & \\
\hline 0.0057 & 38 & 0 & NORMAL & & 0.004 & 30 & 0 & NORMAL & \\
\hline 0.0057 & 38 & 0 & NORMAL & & 0.004 & 30 & 0 & NORMAL & \\
\hline 0.0057 & 38 & 0 & NORMAL & & 0.004 & 30 & 0 & NORMAL & \\
\hline 0.0057 & 38 & 0 & NORMAL & & 0.004 & 30 & 0 & NORMAL & \\
\hline 0.0057 & 38 & 0 & NORMAL & & 0.004 & 31 & 0 & NORMAL & \\
\hline 0.0057 & 38 & 0 & NORMAL & & 0.004 & 32 & 0 & NORMAL & \\
\hline 0.0057 & 38 & 0 & NORMAL & & 0.004 & 32 & 0 & NORMAL & \\
\hline 0.0057 & 38 & 0 & 21 & 0.004589 & 0.004 & 32 & 0 & NORMAL & \\
\hline 0.0057 & 38 & 0 & NORMAL & & 0.004 & 33 & 0 & NORMAL & \\
\hline 0.0057 & 38 & 0 & NORMAL & & 0.004 & 33 & 0 & NORMAL & \\
\hline 0.0057 & 38 & 0 & NORMAL & & 0.004 & 34 & 0 & NORMAL & \\
\hline 0.0057 & 38 & 0 & NORMAL & & 0.004 & 34 & 0 & NORMAL & \\
\hline 0.0057 & 38 & 0 & NORMAL & & 0.004 & 34 & 0 & NORMAL & \\
\hline 0.0057 & 38 & 0 & NORMAL & & 0.0041 & 22 & 0 & NORMAL & 0.00330 \\
\hline 0.0057 & 38 & 0 & NORMAL & & 0.0041 & 22 & 0 & NORMAL & \\
\hline 0.0057 & 38 & 0 & NORMAL & & 0.0041 & 26 & 0 & NORMAL & \\
\hline 0.0057 & 38 & 0 & NORMAL & & 0.0041 & 30 & 0 & NORMAL & \\
\hline
\end{tabular}




\begin{tabular}{|c|c|c|c|c|c|c|c|c|c|}
\hline 0.0057 & 38 & 0 & NORMAL & & 0.0041 & 30 & 0 & NORMAL & \\
\hline 0.0057 & 38 & 0 & NORMAL & & 0.0041 & 32 & 0 & NORMAL & \\
\hline 0.0057 & 38 & 0 & NORMAL & & 0.0041 & 34 & 0 & NORMAL & \\
\hline 0.0057 & 38 & 0 & NORMAL & & 0.0041 & 34 & 0 & NORMAL & \\
\hline 0.0057 & 38 & 0 & NORMAL & & 0.0041 & 34 & 0 & NORMAL & \\
\hline 0.0057 & 38 & 0 & NORMAL & & 0.0042 & 18 & 0 & NORMAL & 0.00338 \\
\hline 0.0057 & 38 & 0 & NORMAL & & 0.0042 & 23 & 0 & NORMAL & \\
\hline 0.0057 & 38 & 0 & NORMAL & & 0.0042 & 24 & 0 & NORMAL & \\
\hline 0.0057 & 38 & 0 & NORMAL & & 0.0042 & 26 & 0 & NORMAL & \\
\hline 0.0057 & 38 & 0 & NORMAL & & 0.0042 & 27 & 3 & NORMAL & 0.05753 \\
\hline 0.0057 & 38 & 0 & NORMAL & & 0.0042 & 30 & 0 & NORMAL & \\
\hline 0.0057 & 38 & 0 & NORMAL & & 0.0042 & 31 & 0 & NORMAL & \\
\hline 0.0057 & 38 & 0 & NORMAL & & 0.0042 & 33 & 0 & NORMAL & \\
\hline 0.0057 & 38 & 0 & NORMAL & & 0.0043 & 22 & 0 & NORMAL & 0.00346 \\
\hline 0.0057 & 38 & 1 & NORMAL & 0.0780729 & 0.0043 & 22 & 0 & NORMAL & \\
\hline 0.0055 & 36 & 0 & NORMAL & 0.0044275 & 0.0043 & 23 & 0 & NORMAL & \\
\hline 0.005 & 35 & 0 & NORMAL & 0.004025 & 0.0043 & 23 & 0 & NORMAL & \\
\hline 0.0048 & 37 & 0 & NORMAL & 0.003864 & 0.0043 & 24 & 0 & NORMAL & \\
\hline 0.0047 & 35 & 0 & NORMAL & 0.0037835 & 0.0043 & 25 & 0 & NORMAL & \\
\hline 0.0045 & 37 & 0 & NORMAL & 0.0036225 & 0.0043 & 27 & 0 & NORMAL & \\
\hline 0.0045 & 37 & 0 & NORMAL & & 0.0043 & 29 & 0 & NORMAL & \\
\hline 0.0045 & 37 & 0 & NORMAL & & 0.0043 & 30 & 0 & NORMAL & \\
\hline 0.0045 & 37 & 0 & NORMAL & & 0.0043 & 31 & 0 & NORMAL & \\
\hline 0.0045 & 37 & 0 & NORMAL & & 0.0043 & 31 & 0 & NORMAL & \\
\hline 0.0045 & 37 & 0 & NORMAL & & 0.0043 & 32 & 0 & NORMAL & \\
\hline 0.0045 & 37 & 0 & NORMAL & & 0.0043 & 32 & 1 & NORMAL & 0.05890 \\
\hline 0.0045 & 37 & 0 & NORMAL & & 0.0043 & 32 & 0 & NORMAL & \\
\hline 0.0045 & 37 & 0 & NORMAL & & 0.0043 & 32 & 0 & NORMAL & \\
\hline 0.0045 & 37 & 0 & NORMAL & & 0.0043 & 34 & 0 & NORMAL & \\
\hline 0.0045 & 37 & 0 & NORMAL & & 0.0044 & 21 & 0 & NORMAL & 0.00354 \\
\hline 0.0045 & 37 & 1 & NORMAL & 0.0616365 & 0.0044 & 22 & 1 & NORMAL & 0.06027 \\
\hline 0.0045 & 37 & 0 & NORMAL & & 0.0044 & 25 & 0 & NORMAL & \\
\hline 0.0045 & 37 & 0 & NORMAL & & 0.0044 & 25 & 0 & NORMAL & \\
\hline 0.0045 & 37 & 0 & NORMAL & & 0.0044 & 27 & 0 & NORMAL & \\
\hline 0.0045 & 37 & 0 & NORMAL & & 0.0044 & 28 & 0 & NORMAL & \\
\hline 0.0045 & 37 & 0 & NORMAL & & 0.0044 & 30 & 0 & NORMAL & \\
\hline 0.0045 & 37 & 0 & NORMAL & & 0.0044 & 32 & 1 & NORMAL & \\
\hline 0.0045 & 37 & 0 & NORMAL & & 0.0044 & 33 & 0 & NORMAL & \\
\hline 0.0045 & 37 & 0 & NORMAL & & 0.0044 & 33 & 0 & NORMAL & \\
\hline 0.0045 & 37 & 0 & NORMAL & & 0.0045 & 18 & 0 & NORMAL & 0.00362 \\
\hline 0.0045 & 37 & 0 & NORMAL & & 0.0045 & 20 & 0 & NORMAL & \\
\hline 0.0045 & 37 & 0 & NORMAL & & 0.0045 & 21 & 0 & NORMAL & \\
\hline 0.0045 & 37 & 0 & NORMAL & & 0.0045 & 22 & 0 & NORMAL & \\
\hline 0.0045 & 37 & 0 & NORMAL & & 0.0045 & 22 & 1 & NORMAL & 0.06164 \\
\hline 0.0045 & 37 & 0 & NORMAL & & 0.0045 & 25 & 0 & NORMAL & \\
\hline 0.0045 & 37 & 0 & NORMAL & & 0.0045 & 25 & 0 & NORMAL & \\
\hline 0.0045 & 37 & 0 & NORMAL & & 0.0045 & 25 & 0 & NORMAL & \\
\hline
\end{tabular}




\begin{tabular}{|c|c|c|c|c|c|c|c|c|c|}
\hline 0.0045 & 37 & 0 & NORMAL & & 0.0045 & 26 & 0 & NORMAL & \\
\hline 0.0045 & 37 & 0 & NORMAL & & 0.0045 & 28 & 0 & NORMAL & \\
\hline 0.0045 & 37 & 0 & NORMAL & & 0.0045 & 28 & 0 & NORMAL & \\
\hline 0.0045 & 37 & 0 & NORMAL & & 0.0045 & 28 & 0 & NORMAL & \\
\hline 0.0045 & 37 & 0 & NORMAL & & 0.0045 & 29 & 0 & NORMAL & \\
\hline 0.0045 & 37 & 0 & NORMAL & & 0.0045 & 29 & 0 & NORMAL & \\
\hline 0.0045 & 37 & 0 & NORMAL & & 0.0045 & 29 & 0 & NORMAL & \\
\hline 0.0045 & 37 & 0 & NORMAL & & 0.0045 & 29 & 0 & NORMAL & \\
\hline 0.0045 & 37 & 0 & NORMAL & & 0.0045 & 29 & 0 & NORMAL & \\
\hline 0.0045 & 37 & 0 & 21 & 0.003626 & 0.0045 & 30 & 0 & NORMAL & \\
\hline 0.0045 & 37 & 1 & NORMAL & & 0.0045 & 32 & 0 & NORMAL & \\
\hline 0.0045 & 37 & 0 & NORMAL & & 0.0045 & 33 & 0 & NORMAL & \\
\hline 0.0045 & 37 & 0 & NORMAL & & 0.0045 & 33 & 0 & NORMAL & \\
\hline 0.0045 & 37 & 0 & NORMAL & & 0.0045 & 33 & 0 & NORMAL & \\
\hline 0.0045 & 37 & 0 & NORMAL & & 0.0045 & 33 & 0 & NORMAL & \\
\hline 0.0045 & 37 & 0 & NORMAL & & 0.0045 & 34 & 0 & NORMAL & \\
\hline 0.0045 & 37 & 0 & NORMAL & & 0.0045 & 34 & 0 & NORMAL & \\
\hline 0.0045 & 37 & 0 & NORMAL & & 0.0046 & 22 & 0 & NORMAL & 0.00370 \\
\hline 0.0045 & 37 & 1 & NORMAL & & 0.0046 & 26 & 0 & NORMAL & \\
\hline 0.0045 & 37 & 0 & 21 & 0.003623 & 0.0046 & 27 & 0 & NORMAL & \\
\hline 0.0045 & 37 & 0 & NORMAL & & 0.0046 & 29 & 0 & NORMAL & \\
\hline 0.0045 & 37 & 0 & NORMAL & & 0.0046 & 30 & 0 & NORMAL & \\
\hline 0.0045 & 37 & 0 & NORMAL & & 0.0046 & 33 & 0 & NORMAL & \\
\hline 0.0045 & 37 & 0 & NORMAL & & 0.0046 & 33 & 0 & NORMAL & \\
\hline 0.0045 & 37 & 0 & NORMAL & & 0.0046 & 34 & 1 & NORMAL & 0.06301 \\
\hline 0.0045 & 37 & 1 & NORMAL & & 0.0046 & 34 & 0 & NORMAL & \\
\hline 0.0045 & 37 & 0 & NORMAL & & 0.0047 & 22 & 0 & NORMAL & 0.00378 \\
\hline 0.0045 & 37 & 0 & NORMAL & & 0.0047 & 23 & 0 & NORMAL & \\
\hline 0.0045 & 37 & 0 & NORMAL & & 0.0047 & 26 & 0 & NORMAL & \\
\hline 0.0045 & 37 & 0 & NORMAL & & 0.0047 & 27 & 1 & NORMAL & 0.06438 \\
\hline 0.0045 & 37 & 0 & NORMAL & & 0.0047 & 29 & 0 & NORMAL & \\
\hline 0.0045 & 37 & 0 & NORMAL & & 0.0047 & 29 & 0 & NORMAL & \\
\hline 0.0045 & 37 & 0 & NORMAL & & 0.0047 & 30 & 0 & NORMAL & \\
\hline 0.0045 & 37 & 0 & NORMAL & & 0.0047 & 30 & 0 & NORMAL & \\
\hline 0.0045 & 37 & 0 & NORMAL & & 0.0047 & 32 & 0 & NORMAL & \\
\hline 0.0045 & 37 & 0 & NORMAL & & 0.0047 & 32 & 0 & NORMAL & \\
\hline 0.0045 & 37 & 0 & NORMAL & & 0.0048 & 25 & 0 & NORMAL & 0.00386 \\
\hline 0.0045 & 37 & 0 & NORMAL & & 0.0048 & 27 & 0 & NORMAL & \\
\hline 0.0045 & 37 & 0 & NORMAL & & 0.0048 & 28 & 0 & NORMAL & \\
\hline 0.0045 & 37 & 0 & NORMAL & & 0.0048 & 31 & 0 & NORMAL & \\
\hline 0.0045 & 37 & 0 & NORMAL & & 0.0048 & 31 & 0 & NORMAL & \\
\hline 0.0045 & 37 & 0 & NORMAL & & 0.0048 & 31 & 0 & NORMAL & \\
\hline 0.0045 & 37 & 0 & NORMAL & & 0.0048 & 33 & 0 & NORMAL & \\
\hline 0.0045 & 37 & 0 & NORMAL & & 0.0048 & 34 & 0 & NORMAL & \\
\hline 0.0045 & 37 & 0 & NORMAL & & 0.0049 & 19 & 0 & NORMAL & 0.00394 \\
\hline 0.0045 & 37 & 0 & NORMAL & & 0.0049 & 21 & 0 & NORMAL & \\
\hline 0.0045 & 37 & 0 & NORMAL & & 0.0049 & 23 & 0 & NORMAL & \\
\hline
\end{tabular}




\begin{tabular}{|c|c|c|c|c|c|c|c|c|c|}
\hline 0.0045 & 37 & 0 & NORMAL & & 0.0049 & 26 & 0 & NORMAL & \\
\hline 0.0045 & 37 & 0 & NORMAL & & 0.0049 & 28 & 0 & NORMAL & \\
\hline 0.0045 & 37 & 0 & NORMAL & & 0.0049 & 29 & 0 & NORMAL & \\
\hline 0.0045 & 37 & 0 & NORMAL & & 0.0049 & 31 & 0 & NORMAL & \\
\hline 0.0045 & 37 & 0 & NORMAL & & 0.005 & 17 & 0 & NORMAL & 0.00403 \\
\hline 0.0045 & 37 & 0 & NORMAL & & 0.005 & 19 & 0 & NORMAL & \\
\hline 0.0045 & 37 & 0 & NORMAL & & 0.005 & 22 & 0 & NORMAL & \\
\hline 0.0045 & 37 & 0 & NORMAL & & 0.005 & 23 & 0 & NORMAL & \\
\hline 0.0045 & 37 & 0 & NORMAL & & 0.005 & 24 & 0 & NORMAL & \\
\hline 0.0045 & 37 & 0 & NORMAL & & 0.005 & 26 & 0 & NORMAL & \\
\hline 0.0045 & 37 & 0 & NORMAL & & 0.005 & 27 & 0 & NORMAL & \\
\hline 0.0045 & 37 & 0 & NORMAL & & 0.005 & 28 & 0 & NORMAL & \\
\hline 0.0045 & 37 & 0 & NORMAL & & 0.005 & 29 & 0 & NORMAL & \\
\hline 0.0045 & 37 & 0 & NORMAL & & 0.005 & 31 & 0 & NORMAL & \\
\hline 0.0045 & 37 & 0 & NORMAL & & 0.005 & 33 & 0 & NORMAL & \\
\hline 0.0045 & 37 & 0 & NORMAL & & 0.005 & 33 & 0 & NORMAL & \\
\hline 0.0045 & 37 & 0 & NORMAL & & 0.005 & 34 & 1 & NORMAL & 0.06849 \\
\hline 0.0045 & 37 & 0 & NORMAL & & 0.005 & 34 & 1 & NORMAL & \\
\hline 0.0045 & 37 & 0 & NORMAL & & 0.0051 & 19 & 0 & NORMAL & 0.00411 \\
\hline 0.0045 & 37 & 0 & NORMAL & & 0.0051 & 25 & 0 & NORMAL & \\
\hline 0.0045 & 37 & 0 & NORMAL & & 0.0051 & 26 & 0 & NORMAL & \\
\hline 0.0045 & 37 & 0 & NORMAL & & 0.0051 & 28 & 0 & NORMAL & \\
\hline 0.0045 & 37 & 0 & NORMAL & & 0.0051 & 31 & 0 & NORMAL & \\
\hline 0.0045 & 37 & 0 & NORMAL & & 0.0051 & 34 & 0 & NORMAL & \\
\hline 0.0045 & 37 & 0 & NORMAL & & 0.0051 & 34 & 0 & NORMAL & \\
\hline 0.0045 & 37 & 0 & NORMAL & & 0.0052 & 16 & 0 & NORMAL & 0.00419 \\
\hline 0.0045 & 37 & 0 & NORMAL & & 0.0052 & 27 & 0 & NORMAL & \\
\hline 0.0045 & 37 & 0 & NORMAL & & 0.0052 & 29 & 0 & NORMAL & \\
\hline 0.0045 & 37 & 0 & NORMAL & & 0.0052 & 29 & 0 & NORMAL & \\
\hline 0.0045 & 37 & 0 & NORMAL & & 0.0053 & 19 & 0 & NORMAL & 0.00427 \\
\hline 0.0045 & 37 & 0 & NORMAL & & 0.0053 & 19 & 0 & NORMAL & \\
\hline 0.0045 & 37 & 0 & NORMAL & & 0.0053 & 20 & 0 & NORMAL & \\
\hline 0.0045 & 37 & 0 & NORMAL & & 0.0053 & 22 & 0 & NORMAL & \\
\hline 0.0045 & 37 & 0 & NORMAL & & 0.0053 & 22 & 0 & NORMAL & \\
\hline 0.0045 & 37 & 0 & NORMAL & & 0.0053 & 22 & 0 & NORMAL & \\
\hline 0.0045 & 37 & 0 & NORMAL & & 0.0053 & 22 & 0 & NORMAL & \\
\hline 0.0045 & 37 & 0 & NORMAL & & 0.0053 & 25 & 0 & NORMAL & \\
\hline 0.0045 & 37 & 1 & NORMAL & 0.0616365 & 0.0053 & 25 & 0 & NORMAL & \\
\hline 0.0045 & 37 & 0 & 21 & 0.003623 & 0.0053 & 25 & 0 & NORMAL & \\
\hline 0.0045 & 37 & 0 & NORMAL & & 0.0053 & 31 & 0 & NORMAL & \\
\hline 0.0045 & 37 & 0 & NORMAL & & 0.0054 & 22 & 0 & NORMAL & 0.00435 \\
\hline 0.0045 & 37 & 0 & NORMAL & & 0.0054 & 22 & 0 & NORMAL & \\
\hline 0.0045 & 37 & 0 & NORMAL & & 0.0054 & 23 & 0 & NORMAL & \\
\hline 0.0045 & 37 & 0 & NORMAL & & 0.0054 & 25 & 0 & NORMAL & \\
\hline 0.0045 & 37 & 1 & NORMAL & & 0.0054 & 30 & 0 & NORMAL & \\
\hline 0.0045 & 37 & 0 & NORMAL & & 0.0054 & 32 & 0 & NORMAL & \\
\hline 0.0045 & 37 & 0 & NORMAL & & 0.0055 & 17 & 0 & NORMAL & 0.00443 \\
\hline
\end{tabular}




\begin{tabular}{|c|c|c|c|c|c|c|c|c|c|}
\hline 0.0045 & 37 & 0 & NORMAL & & 0.0055 & 18 & 0 & NORMAL & \\
\hline 0.0045 & 37 & 0 & NORMAL & & 0.0055 & 25 & 0 & NORMAL & \\
\hline 0.0045 & 37 & 0 & NORMAL & & 0.0055 & 30 & 0 & NORMAL & \\
\hline 0.0045 & 37 & 0 & NORMAL & & 0.0055 & 33 & 0 & NORMAL & \\
\hline 0.0045 & 37 & 0 & NORMAL & & 0.0056 & 18 & 0 & NORMAL & 0.00451 \\
\hline 0.0045 & 37 & 0 & NORMAL & & 0.0056 & 27 & 0 & NORMAL & \\
\hline 0.0045 & 37 & 0 & NORMAL & & 0.0056 & 29 & 0 & NORMAL & \\
\hline 0.0045 & 37 & 0 & NORMAL & & 0.0056 & 31 & 0 & NORMAL & \\
\hline 0.0045 & 37 & 0 & NORMAL & & 0.0056 & 32 & 0 & NORMAL & \\
\hline 0.0045 & 37 & 0 & NORMAL & & 0.0056 & 32 & 0 & NORMAL & \\
\hline 0.0045 & 37 & 0 & NORMAL & & 0.0056 & 32 & 0 & NORMAL & \\
\hline 0.0045 & 37 & 0 & NORMAL & & 0.0056 & 32 & 0 & NORMAL & \\
\hline 0.0045 & 37 & 0 & NORMAL & & 0.0056 & 33 & 0 & NORMAL & \\
\hline 0.0045 & 37 & 0 & NORMAL & & 0.0056 & 34 & 0 & NORMAL & \\
\hline 0.0045 & 37 & 0 & NORMAL & & 0.0057 & 20 & 0 & NORMAL & 0.00459 \\
\hline 0.0045 & 37 & 0 & NORMAL & & 0.0057 & 24 & 0 & NORMAL & \\
\hline 0.0045 & 37 & 0 & NORMAL & & 0.0057 & 25 & 0 & NORMAL & \\
\hline 0.0045 & 37 & 0 & NORMAL & & 0.0057 & 27 & 0 & NORMAL & \\
\hline 0.0045 & 37 & 0 & NORMAL & & 0.0057 & 27 & 0 & NORMAL & \\
\hline 0.0045 & 37 & 0 & NORMAL & & 0.0057 & 28 & 0 & NORMAL & \\
\hline 0.0045 & 37 & 0 & NORMAL & & 0.0057 & 28 & 0 & NORMAL & \\
\hline 0.0045 & 37 & 0 & NORMAL & & 0.0057 & 28 & 0 & NORMAL & \\
\hline 0.0045 & 37 & 0 & NORMAL & & 0.0057 & 28 & 0 & NORMAL & \\
\hline 0.0045 & 37 & 0 & NORMAL & & 0.0057 & 28 & 0 & NORMAL & \\
\hline 0.0045 & 37 & 0 & NORMAL & & 0.0057 & 29 & 1 & 21 & 0.07807 \\
\hline 0.0045 & 37 & 0 & NORMAL & & 0.0057 & 29 & 0 & NORMAL & \\
\hline 0.0045 & 37 & 0 & NORMAL & & 0.0057 & 29 & 0 & NORMAL & \\
\hline 0.0045 & 37 & 0 & NORMAL & & 0.0057 & 30 & 0 & NORMAL & \\
\hline 0.0045 & 37 & 0 & NORMAL & & 0.0057 & 32 & 0 & NORMAL & \\
\hline 0.0045 & 37 & 0 & NORMAL & & 0.0057 & 32 & 0 & NORMAL & \\
\hline 0.0045 & 37 & 0 & NORMAL & & 0.0057 & 33 & 0 & NORMAL & \\
\hline 0.0045 & 37 & 0 & NORMAL & & 0.0057 & 33 & 0 & NORMAL & \\
\hline 0.0045 & 37 & 0 & NORMAL & & 0.0057 & 33 & 0 & NORMAL & \\
\hline 0.0045 & 37 & 0 & NORMAL & & 0.0057 & 33 & 0 & NORMAL & \\
\hline 0.0045 & 37 & 0 & NORMAL & & 0.0057 & 34 & 0 & NORMAL & \\
\hline 0.0045 & 37 & 0 & NORMAL & & 0.0057 & 34 & 0 & NORMAL & \\
\hline 0.0044 & 38 & 0 & NORMAL & 0.003542 & 0.0057 & 34 & 0 & NORMAL & \\
\hline 0.0042 & 35 & 0 & NORMAL & 0.003381 & 0.0058 & 17 & 0 & NORMAL & 0.00467 \\
\hline 0.0041 & 37 & 0 & NORMAL & 0.0033005 & 0.0058 & 24 & 0 & NORMAL & \\
\hline 0.004 & 36 & 0 & NORMAL & 0.00322 & 0.0058 & 24 & 0 & NORMAL & \\
\hline 0.004 & 36 & 0 & NORMAL & 0.00322 & 0.0058 & 25 & 0 & NORMAL & \\
\hline 0.0037 & 35 & 0 & NORMAL & 0.0029785 & 0.0058 & 28 & 0 & NORMAL & \\
\hline 0.0036 & 35 & 0 & NORMAL & & 0.0058 & 31 & 0 & NORMAL & \\
\hline 0.0035 & 35 & 0 & NORMAL & & 0.0058 & 32 & 0 & NORMAL & \\
\hline 0.0035 & 36 & 0 & NORMAL & & 0.0058 & 32 & 0 & NORMAL & \\
\hline 0.0035 & 36 & 0 & NORMAL & & 0.0058 & 33 & 0 & NORMAL & \\
\hline 0.0035 & 36 & 0 & NORMAL & & 0.0059 & 17 & 0 & NORMAL & 0.00475 \\
\hline
\end{tabular}




\begin{tabular}{|c|c|c|c|c|c|c|c|c|c|}
\hline 0.0035 & 36 & 0 & NORMAL & & 0.0059 & 25 & 0 & NORMAL & \\
\hline 0.0035 & 36 & 0 & NORMAL & & 0.0059 & 27 & 0 & NORMAL & \\
\hline 0.0035 & 36 & 0 & NORMAL & & 0.0059 & 34 & 0 & NORMAL & \\
\hline 0.0035 & 36 & 0 & NORMAL & & 0.006 & 21 & 0 & NORMAL & 0.00483 \\
\hline 0.0035 & 36 & 1 & NORMAL & 0.0479395 & 0.006 & 24 & 0 & NORMAL & \\
\hline 0.0035 & 36 & 0 & NORMAL & & 0.006 & 24 & 0 & NORMAL & \\
\hline 0.0035 & 36 & 0 & NORMAL & & 0.006 & 25 & 0 & NORMAL & \\
\hline 0.0035 & 36 & 0 & NORMAL & & 0.006 & 31 & 0 & NORMAL & \\
\hline 0.0035 & 36 & 0 & NORMAL & & 0.006 & 34 & 0 & NORMAL & \\
\hline 0.0035 & 36 & 0 & NORMAL & & 0.0061 & 20 & 0 & NORMAL & 0.00491 \\
\hline 0.0035 & 36 & 0 & NORMAL & & 0.0061 & 27 & 0 & NORMAL & \\
\hline 0.0035 & 36 & 0 & NORMAL & & 0.0061 & 27 & 0 & NORMAL & \\
\hline 0.0035 & 36 & 0 & NORMAL & & 0.0061 & 32 & 0 & NORMAL & \\
\hline 0.0035 & 36 & 0 & NORMAL & & 0.0062 & 19 & 0 & NORMAL & 0.00499 \\
\hline 0.0035 & 36 & 0 & NORMAL & & 0.0062 & 33 & 0 & NORMAL & \\
\hline 0.0035 & 36 & 0 & NORMAL & & 0.0063 & 21 & 0 & NORMAL & 0.00507 \\
\hline 0.0035 & 36 & 0 & NORMAL & & 0.0063 & 21 & 0 & NORMAL & \\
\hline 0.0035 & 36 & 1 & NORMAL & 0.0479395 & 0.0063 & 25 & 0 & NORMAL & \\
\hline 0.0035 & 36 & 0 & NORMAL & & 0.0063 & 26 & 0 & NORMAL & \\
\hline 0.0035 & 36 & 0 & NORMAL & & 0.0063 & 26 & 0 & NORMAL & \\
\hline 0.0035 & 36 & 0 & NORMAL & & 0.0063 & 29 & 0 & NORMAL & \\
\hline 0.0035 & 36 & 0 & NORMAL & & 0.0064 & 26 & 0 & NORMAL & 24.35200 \\
\hline 0.0035 & 36 & 0 & NORMAL & & 0.0064 & 30 & 0 & NORMAL & \\
\hline 0.0035 & 36 & 1 & NORMAL & 0.0479395 & 0.0064 & 30 & 0 & NORMAL & \\
\hline 0.0035 & 36 & 0 & NORMAL & & 0.0064 & 31 & 0 & NORMAL & \\
\hline 0.0035 & 36 & 0 & NORMAL & & 0.0064 & 31 & 0 & NORMAL & \\
\hline 0.0035 & 36 & 0 & NORMAL & & 0.0065 & 20 & 1 & NORMAL & 0.08903 \\
\hline 0.0035 & 36 & 0 & NORMAL & & 0.0065 & 27 & 0 & NORMAL & 0.00523 \\
\hline 0.0035 & 36 & 0 & NORMAL & & 0.0065 & 28 & 0 & NORMAL & \\
\hline 0.0035 & 36 & 0 & NORMAL & & 0.0065 & 30 & 0 & NORMAL & \\
\hline 0.0035 & 36 & 0 & NORMAL & & 0.0065 & 30 & 0 & NORMAL & \\
\hline 0.0035 & 36 & 0 & NORMAL & & 0.0066 & 27 & 0 & NORMAL & 0.00531 \\
\hline 0.0035 & 36 & 0 & NORMAL & & 0.0066 & 28 & 0 & NORMAL & \\
\hline 0.0035 & 36 & 0 & NORMAL & & 0.0066 & 28 & 0 & NORMAL & \\
\hline 0.0035 & 36 & 0 & NORMAL & & 0.0066 & 28 & 0 & NORMAL & \\
\hline 0.0035 & 36 & 0 & NORMAL & & 0.0066 & 28 & 0 & NORMAL & \\
\hline 0.0035 & 36 & 0 & NORMAL & & 0.0066 & 28 & 0 & NORMAL & \\
\hline 0.0035 & 36 & 0 & NORMAL & & 0.0067 & 18 & 0 & NORMAL & 0.00539 \\
\hline 0.0035 & 36 & 0 & NORMAL & & 0.0067 & 28 & 0 & NORMAL & \\
\hline 0.0035 & 36 & 0 & NORMAL & & 0.0067 & 30 & 4 & NORMAL & 0.09177 \\
\hline 0.0035 & 36 & 0 & NORMAL & & 0.0068 & 24 & 0 & NORMAL & 0.00547 \\
\hline 0.0035 & 36 & 0 & NORMAL & & 0.0068 & 27 & 0 & NORMAL & \\
\hline 0.0035 & 36 & 0 & NORMAL & & 0.0068 & 27 & 0 & NORMAL & \\
\hline 0.0035 & 36 & 0 & NORMAL & & 0.0068 & 29 & 0 & NORMAL & \\
\hline 0.0035 & 36 & 0 & NORMAL & & 0.0068 & 30 & 0 & NORMAL & \\
\hline 0.0035 & 36 & 0 & NORMAL & & 0.0068 & 31 & 0 & NORMAL & \\
\hline 0.0035 & 36 & 0 & NORMAL & & 0.0069 & 19 & 0 & NORMAL & 0.00555 \\
\hline
\end{tabular}




\begin{tabular}{|c|c|c|c|c|c|c|c|c|}
\hline 0.0035 & 36 & 0 & NORMAL & 0.0069 & 19 & 0 & NORMAL & \\
\hline 0.0035 & 36 & 0 & NORMAL & 0.0069 & 28 & 0 & NORMAL & \\
\hline 0.0035 & 36 & 0 & NORMAL & 0.0069 & 33 & 0 & NORMAL & \\
\hline 0.0035 & 36 & 0 & NORMAL & 0.0069 & 33 & 0 & NORMAL & \\
\hline 0.0035 & 36 & 0 & NORMAL & 0.0069 & 34 & 0 & NORMAL & \\
\hline 0.0035 & 36 & 0 & NORMAL & 0.007 & 17 & 0 & NORMAL & 0.00564 \\
\hline 0.0035 & 36 & 0 & NORMAL & 0.007 & 22 & 0 & NORMAL & \\
\hline 0.0035 & 36 & 0 & NORMAL & 0.007 & 25 & 0 & NORMAL & \\
\hline 0.0035 & 36 & 0 & NORMAL & 0.007 & 29 & 0 & NORMAL & \\
\hline 0.0035 & 36 & 0 & NORMAL & 0.007 & 31 & 0 & NORMAL & \\
\hline 0.0035 & 36 & 0 & NORMAL & 0.007 & 33 & 0 & NORMAL & \\
\hline 0.0035 & 36 & 0 & NORMAL & 0.0071 & 20 & 0 & NORMAL & 0.00572 \\
\hline 0.0035 & 36 & 0 & NORMAL & 0.0071 & 25 & 0 & NORMAL & \\
\hline 0.0035 & 36 & 0 & NORMAL & 0.0071 & 31 & 0 & NORMAL & \\
\hline 0.0035 & 36 & 0 & NORMAL & 0.0071 & 34 & 0 & NORMAL & \\
\hline 0.0035 & 36 & 0 & NORMAL & 0.0071 & 34 & 0 & NORMAL & \\
\hline 0.0035 & 36 & 0 & NORMAL & 0.0072 & 18 & 0 & NORMAL & 0.00580 \\
\hline 0.0035 & 36 & 0 & NORMAL & 0.0072 & 20 & 0 & NORMAL & \\
\hline 0.0035 & 36 & 0 & NORMAL & 0.0072 & 25 & 0 & NORMAL & \\
\hline 0.0035 & 36 & 0 & NORMAL & 0.0072 & 30 & 0 & NORMAL & \\
\hline 0.0035 & 36 & 0 & NORMAL & 0.0072 & 30 & 0 & NORMAL & \\
\hline 0.0035 & 36 & 0 & NORMAL & 0.0072 & 31 & 0 & NORMAL & \\
\hline 0.0035 & 36 & 0 & NORMAL & 0.0072 & 31 & 0 & NORMAL & \\
\hline 0.0035 & 36 & 0 & NORMAL & 0.0073 & 22 & 0 & NORMAL & 0.00588 \\
\hline 0.0035 & 36 & 0 & NORMAL & 0.0073 & 22 & 0 & NORMAL & \\
\hline 0.0035 & 36 & 0 & NORMAL & 0.0073 & 23 & 0 & NORMAL & \\
\hline 0.0035 & 36 & 0 & NORMAL & 0.0073 & 31 & 0 & NORMAL & \\
\hline 0.0035 & 36 & 0 & NORMAL & 0.0074 & 25 & 0 & NORMAL & 0.00596 \\
\hline 0.0035 & 36 & 0 & NORMAL & 0.0074 & 27 & 0 & NORMAL & \\
\hline 0.0035 & 36 & 0 & NORMAL & 0.0074 & 27 & 0 & NORMAL & \\
\hline 0.0035 & 36 & 0 & NORMAL & 0.0074 & 28 & 0 & NORMAL & \\
\hline 0.0035 & 36 & 0 & NORMAL & 0.0074 & 30 & 0 & NORMAL & \\
\hline 0.0035 & 36 & 0 & NORMAL & 0.0074 & 31 & 0 & NORMAL & \\
\hline 0.0035 & 36 & 0 & NORMAL & 0.0074 & 31 & 0 & NORMAL & \\
\hline 0.0035 & 36 & 0 & NORMAL & 0.0074 & 32 & 0 & NORMAL & \\
\hline 0.0035 & 36 & 0 & NORMAL & 0.0074 & 33 & 0 & NORMAL & \\
\hline 0.0035 & 36 & 0 & NORMAL & 0.0074 & 34 & 0 & NORMAL & \\
\hline 0.0035 & 36 & 0 & NORMAL & 0.0074 & 34 & 0 & NORMAL & \\
\hline 0.0035 & 36 & 0 & NORMAL & 0.0075 & 23 & 0 & NORMAL & 0.00604 \\
\hline 0.0035 & 36 & 0 & NORMAL & 0.0075 & 25 & 0 & NORMAL & \\
\hline 0.0035 & 36 & 0 & NORMAL & 0.0075 & 26 & 0 & NORMAL & \\
\hline 0.0035 & 36 & 0 & NORMAL & 0.0075 & 29 & 0 & NORMAL & \\
\hline 0.0035 & 36 & 0 & NORMAL & 0.0076 & 22 & 0 & NORMAL & 0.00612 \\
\hline 0.0035 & 36 & 0 & NORMAL & 0.0076 & 33 & 0 & NORMAL & \\
\hline 0.0035 & 36 & 0 & NORMAL & 0.0077 & 17 & 0 & NORMAL & 0.00620 \\
\hline 0.0035 & 36 & 0 & NORMAL & 0.0077 & 23 & 0 & NORMAL & \\
\hline 0.0035 & 36 & 0 & NORMAL & 0.0077 & 23 & 0 & NORMAL & \\
\hline
\end{tabular}




\begin{tabular}{|c|c|c|c|c|c|c|c|c|}
\hline 0.0035 & 36 & 0 & NORMAL & 0.00775 & 27 & 0 & NORMAL & 0.00624 \\
\hline 0.0035 & 36 & 0 & NORMAL & 0.0078 & 19 & 0 & NORMAL & 0.00628 \\
\hline 0.0035 & 36 & 0 & NORMAL & 0.0078 & 27 & 0 & NORMAL & \\
\hline 0.0035 & 36 & 0 & NORMAL & 0.0078 & 28 & 0 & NORMAL & \\
\hline 0.0035 & 36 & 0 & NORMAL & 0.0078 & 28 & 0 & NORMAL & \\
\hline 0.0035 & 36 & 0 & NORMAL & 0.0078 & 30 & 0 & NORMAL & \\
\hline 0.0035 & 36 & 0 & NORMAL & 0.0078 & 30 & 0 & NORMAL & \\
\hline 0.0035 & 36 & 0 & NORMAL & 0.0078 & 31 & 0 & NORMAL & \\
\hline 0.0035 & 36 & 0 & NORMAL & 0.0078 & 31 & 0 & NORMAL & \\
\hline 0.0035 & 36 & 0 & NORMAL & 0.0079 & 27 & 0 & NORMAL & 0.00636 \\
\hline 0.0035 & 36 & 0 & NORMAL & 0.0079 & 34 & 0 & NORMAL & \\
\hline 0.0035 & 36 & 0 & NORMAL & 0.008 & 22 & 0 & NORMAL & 0.00644 \\
\hline 0.0035 & 36 & 0 & NORMAL & 0.008 & 25 & 0 & NORMAL & \\
\hline 0.0035 & 36 & 0 & NORMAL & 0.008 & 25 & 0 & NORMAL & \\
\hline 0.0035 & 36 & 0 & NORMAL & 0.008 & 30 & 0 & NORMAL & \\
\hline 0.0035 & 36 & 0 & NORMAL & 0.008 & 31 & 0 & NORMAL & \\
\hline 0.0035 & 36 & 0 & NORMAL & 0.0081 & 25 & 0 & NORMAL & 0.00652 \\
\hline 0.0035 & 36 & 0 & NORMAL & 0.0081 & 28 & 0 & NORMAL & \\
\hline 0.0035 & 36 & 0 & NORMAL & 0.0081 & 28 & 0 & NORMAL & \\
\hline 0.0035 & 36 & 0 & NORMAL & 0.0081 & 32 & 0 & NORMAL & \\
\hline 0.0035 & 36 & 0 & NORMAL & 0.0081 & 33 & 0 & NORMAL & \\
\hline 0.0035 & 36 & 0 & NORMAL & 0.0083 & 29 & 0 & NORMAL & 0.00668 \\
\hline 0.0035 & 36 & 0 & NORMAL & 0.0083 & 34 & 0 & NORMAL & \\
\hline 0.0035 & 36 & 0 & NORMAL & 0.0085 & 23 & 0 & NORMAL & 0.00684 \\
\hline 0.0035 & 36 & 0 & NORMAL & 0.0085 & 23 & 0 & NORMAL & \\
\hline 0.0035 & 36 & 0 & NORMAL & 0.0085 & 24 & 0 & NORMAL & \\
\hline 0.0035 & 36 & 0 & NORMAL & 0.0085 & 26 & 0 & NORMAL & \\
\hline 0.0035 & 36 & 0 & NORMAL & 0.0085 & 28 & 0 & NORMAL & \\
\hline 0.0035 & 36 & 0 & NORMAL & 0.0085 & 28 & 0 & NORMAL & \\
\hline 0.0035 & 36 & 0 & NORMAL & 0.0085 & 29 & 0 & NORMAL & \\
\hline 0.0035 & 36 & 0 & NORMAL & 0.0086 & 27 & 0 & NORMAL & 0.00692 \\
\hline 0.0035 & 36 & 0 & NORMAL & 0.0086 & 28 & 0 & NORMAL & \\
\hline 0.0035 & 36 & 0 & NORMAL & 0.0086 & 28 & 0 & NORMAL & \\
\hline 0.0035 & 36 & 0 & NORMAL & 0.0086 & 29 & 0 & 21 & 0.00692 \\
\hline 0.0035 & 36 & 0 & NORMAL & 0.0087 & 22 & 0 & NORMAL & 0.00700 \\
\hline 0.0035 & 36 & 0 & NORMAL & 0.0087 & 34 & 0 & NORMAL & \\
\hline 0.0035 & 36 & 0 & NORMAL & 0.0087 & 34 & 0 & NORMAL & \\
\hline 0.0035 & 36 & 0 & NORMAL & 0.0088 & 23 & 0 & NORMAL & 0.00708 \\
\hline 0.0035 & 36 & 0 & NORMAL & 0.0088 & 28 & 0 & NORMAL & \\
\hline 0.0035 & 36 & 0 & NORMAL & 0.0088 & 29 & 0 & NORMAL & \\
\hline 0.0035 & 36 & 0 & NORMAL & 0.0088 & 30 & 0 & NORMAL & \\
\hline 0.0035 & 36 & 0 & NORMAL & 0.009 & 24 & 0 & NORMAL & 0.00725 \\
\hline 0.0035 & 36 & 0 & NORMAL & 0.009 & 24 & 0 & NORMAL & \\
\hline 0.0035 & 36 & 0 & NORMAL & 0.0092 & 28 & 0 & NORMAL & 0.00741 \\
\hline 0.0035 & 36 & 0 & NORMAL & 0.0094 & 17 & 0 & NORMAL & 0.00757 \\
\hline 0.0035 & 36 & 0 & NORMAL & 0.0094 & 19 & 0 & NORMAL & \\
\hline 0.0035 & 36 & 0 & NORMAL & 0.0094 & 19 & 0 & NORMAL & \\
\hline
\end{tabular}




\begin{tabular}{|c|c|c|c|c|c|c|c|c|c|}
\hline 0.0035 & 36 & 0 & NORMAL & & 0.0094 & 25 & 0 & NORMAL & \\
\hline 0.0035 & 36 & 0 & NORMAL & & 0.0094 & 26 & 0 & NORMAL & \\
\hline 0.0035 & 36 & 0 & NORMAL & & 0.0094 & 28 & 0 & NORMAL & \\
\hline 0.0035 & 36 & 0 & NORMAL & & 0.0094 & 28 & 0 & NORMAL & \\
\hline 0.0035 & 36 & 0 & NORMAL & & 0.0094 & 30 & 0 & NORMAL & \\
\hline 0.0035 & 36 & 0 & NORMAL & & 0.0094 & 30 & 0 & NORMAL & \\
\hline 0.0035 & 36 & 0 & NORMAL & & 0.0094 & 33 & 0 & NORMAL & \\
\hline 0.0035 & 36 & 0 & NORMAL & & 0.0095 & 27 & 0 & NORMAL & 0.00765 \\
\hline 0.0035 & 36 & 0 & NORMAL & & 0.0095 & 33 & 0 & NORMAL & \\
\hline 0.0035 & 36 & 0 & NORMAL & & 0.0097 & 31 & 0 & NORMAL & 0.00781 \\
\hline 0.0035 & 36 & 0 & NORMAL & & 0.0097 & 31 & 0 & NORMAL & \\
\hline 0.0035 & 36 & 1 & NORMAL & & 0.0098 & 25 & 0 & NORMAL & 0.00789 \\
\hline 0.0035 & 36 & 0 & NORMAL & & 0.0098 & 26 & 0 & NORMAL & \\
\hline 0.0035 & 36 & 0 & NORMAL & & 0.0098 & 29 & 0 & NORMAL & \\
\hline 0.0035 & 36 & 0 & NORMAL & & 0.0098 & 30 & 0 & NORMAL & \\
\hline 0.0035 & 36 & 0 & NORMAL & & 0.0099 & 19 & 0 & NORMAL & 0.00797 \\
\hline 0.0035 & 36 & 0 & NORMAL & & 0.0099 & 20 & 0 & NORMAL & \\
\hline 0.0035 & 36 & 0 & NORMAL & & 0.0099 & 29 & 0 & NORMAL & \\
\hline 0.0034 & 37 & 0 & NORMAL & 0.002737 & 0.01 & 18 & 0 & NORMAL & 0.00805 \\
\hline 0.0033 & 36 & 0 & NORMAL & 0.0026565 & 0.01 & 22 & 0 & NORMAL & \\
\hline 0.0033 & 36 & 0 & NORMAL & 0.0026565 & 0.01 & 24 & 0 & NORMAL & \\
\hline 0.0029 & 35 & 0 & NORMAL & 0.0023345 & 0.01 & 24 & 0 & NORMAL & \\
\hline 0.0027 & 35 & 0 & NORMAL & 0.0021735 & 0.01 & 24 & 0 & NORMAL & \\
\hline 0.0027 & 35 & 0 & NORMAL & & 0.01 & 32 & 0 & NORMAL & \\
\hline 0.0027 & 35 & 0 & NORMAL & & 0.01 & 32 & 0 & NORMAL & \\
\hline 0.0027 & 35 & 0 & NORMAL & & 0.01 & 34 & 0 & NORMAL & \\
\hline 0.0027 & 35 & 0 & NORMAL & & 0.0101 & 23 & 0 & NORMAL & 0.00813 \\
\hline 0.0027 & 35 & 0 & NORMAL & & 0.0101 & 24 & 0 & NORMAL & \\
\hline 0.0027 & 35 & 0 & NORMAL & & 0.0101 & 31 & 0 & NORMAL & \\
\hline 0.0027 & 35 & 0 & NORMAL & & 0.0102 & 26 & 0 & NORMAL & 0.00821 \\
\hline 0.0027 & 35 & 0 & NORMAL & & 0.0103 & 33 & 0 & NORMAL & 0.00829 \\
\hline 0.0027 & 35 & 1 & NORMAL & 0.0369819 & 0.0104 & 27 & 0 & NORMAL & 0.00837 \\
\hline 0.0027 & 35 & 0 & NORMAL & & 0.0104 & 28 & 0 & NORMAL & \\
\hline 0.0027 & 35 & 0 & NORMAL & & 0.0104 & 29 & 0 & NORMAL & \\
\hline 0.0027 & 35 & 0 & NORMAL & & 0.0104 & 32 & 0 & NORMAL & \\
\hline 0.0027 & 35 & 0 & NORMAL & & 0.0104 & 34 & 0 & NORMAL & \\
\hline 0.0027 & 35 & 0 & NORMAL & & 0.0105 & 23 & 0 & NORMAL & 0.01895 \\
\hline 0.0027 & 35 & 0 & NORMAL & & 0.0105 & 24 & 0 & NORMAL & \\
\hline 0.0027 & 35 & 0 & NORMAL & & 0.0105 & 24 & 0 & NORMAL & \\
\hline 0.0027 & 35 & 0 & NORMAL & & 0.0105 & 30 & 0 & NORMAL & \\
\hline 0.0027 & 35 & 0 & NORMAL & & 0.0106 & 24 & 0 & NORMAL & 0.00853 \\
\hline 0.0027 & 35 & 0 & NORMAL & & 0.0106 & 28 & 0 & NORMAL & \\
\hline 0.0027 & 35 & 0 & NORMAL & & 0.0107 & 14 & 0 & NORMAL & 0.00861 \\
\hline 0.0027 & 35 & 0 & NORMAL & & 0.0107 & 18 & 0 & NORMAL & \\
\hline 0.0027 & 35 & 0 & NORMAL & & 0.0108 & 29 & 0 & NORMAL & 0.00869 \\
\hline 0.0027 & 35 & 0 & NORMAL & & 0.0108 & 32 & 0 & NORMAL & \\
\hline 0.0027 & 35 & 0 & NORMAL & & 0.0108 & 32 & 0 & NORMAL & \\
\hline
\end{tabular}




\begin{tabular}{|c|c|c|c|c|c|c|c|c|c|}
\hline 0.0027 & 35 & 0 & NORMAL & & 0.0108 & 34 & 0 & NORMAL & \\
\hline 0.0027 & 35 & 0 & NORMAL & & 0.0109 & 19 & 0 & NORMAL & 0.00877 \\
\hline 0.0027 & 35 & 0 & NORMAL & & 0.0109 & 20 & 0 & NORMAL & \\
\hline 0.0027 & 35 & 0 & NORMAL & & 0.0109 & 23 & 0 & NORMAL & \\
\hline 0.0027 & 35 & 0 & NORMAL & & 0.0109 & 24 & 0 & NORMAL & \\
\hline 0.0027 & 35 & 0 & NORMAL & & 0.0109 & 29 & 0 & NORMAL & \\
\hline 0.0027 & 35 & 0 & NORMAL & & 0.0109 & 31 & 0 & NORMAL & \\
\hline 0.0027 & 35 & 0 & NORMAL & & 0.0109 & 34 & 0 & NORMAL & \\
\hline 0.0027 & 35 & 0 & NORMAL & & 0.0111 & 32 & 0 & NORMAL & 0.00894 \\
\hline 0.0027 & 35 & 0 & NORMAL & & 0.0114 & 29 & 0 & NORMAL & 0.00918 \\
\hline 0.0027 & 35 & 0 & NORMAL & & 0.0114 & 32 & 0 & NORMAL & \\
\hline 0.0027 & 35 & 0 & NORMAL & & 0.0115 & 29 & 0 & NORMAL & 0.00926 \\
\hline 0.0027 & 35 & 0 & NORMAL & & 0.0116 & 29 & 0 & NORMAL & 0.00934 \\
\hline 0.0027 & 35 & 0 & NORMAL & & 0.0118 & 33 & 0 & NORMAL & 0.00950 \\
\hline 0.0027 & 35 & 0 & NORMAL & & 0.0118 & 33 & 0 & NORMAL & \\
\hline 0.0027 & 35 & 0 & NORMAL & & 0.0119 & 17 & 0 & NORMAL & 0.00958 \\
\hline 0.0027 & 35 & 0 & NORMAL & & 0.0119 & 26 & 0 & NORMAL & \\
\hline 0.0027 & 35 & 0 & NORMAL & & 0.012 & 33 & 0 & NORMAL & 0.00966 \\
\hline 0.0027 & 35 & 0 & NORMAL & & 0.0122 & 18 & 0 & NORMAL & 0.00982 \\
\hline 0.0027 & 35 & 0 & NORMAL & & 0.0122 & 19 & 0 & NORMAL & 0.00982 \\
\hline 0.0027 & 35 & 0 & NORMAL & & 0.0122 & 23 & 0 & NORMAL & \\
\hline 0.0027 & 35 & 0 & NORMAL & & 0.0122 & 26 & 0 & NORMAL & \\
\hline 0.0027 & 35 & 0 & NORMAL & & 0.0122 & 27 & 0 & NORMAL & \\
\hline 0.0027 & 35 & 0 & NORMAL & & 0.0122 & 27 & 0 & NORMAL & \\
\hline 0.0027 & 35 & 0 & NORMAL & & 0.0122 & 28 & 0 & NORMAL & \\
\hline 0.0027 & 35 & 0 & NORMAL & & 0.0122 & 28 & 0 & NORMAL & \\
\hline 0.0027 & 35 & 0 & NORMAL & & 0.0122 & 28 & 0 & NORMAL & \\
\hline 0.0027 & 35 & 0 & NORMAL & & 0.0122 & 29 & 0 & NORMAL & \\
\hline 0.0027 & 35 & 0 & NORMAL & & 0.0125 & 17 & 0 & 21 & 0.01006 \\
\hline 0.0027 & 35 & 0 & NORMAL & & 0.0125 & 24 & 0 & NORMAL & \\
\hline 0.0027 & 35 & 0 & NORMAL & & 0.0125 & 24 & 0 & NORMAL & \\
\hline 0.0027 & 35 & 1 & NORMAL & 0.0369819 & 0.0125 & 32 & 0 & NORMAL & \\
\hline 0.0027 & 35 & 0 & NORMAL & & 0.0125 & 34 & 0 & NORMAL & \\
\hline 0.0027 & 35 & 0 & NORMAL & & 0.0127 & 27 & 0 & NORMAL & 0.01022 \\
\hline 0.0027 & 35 & 0 & NORMAL & & 0.0128 & 34 & 0 & NORMAL & 0.01030 \\
\hline 0.0027 & 35 & 0 & NORMAL & & 0.013 & 31 & 0 & NORMAL & 0.01047 \\
\hline 0.0027 & 35 & 0 & NORMAL & & 0.0132 & 18 & 0 & NORMAL & 0.01063 \\
\hline 0.0027 & 35 & 0 & NORMAL & & 0.0133 & 21 & 0 & NORMAL & 0.01071 \\
\hline 0.0027 & 35 & 0 & NORMAL & & 0.0133 & 22 & 0 & NORMAL & \\
\hline 0.0027 & 35 & 0 & NORMAL & & 0.0133 & 23 & 0 & NORMAL & \\
\hline 0.0027 & 35 & 0 & NORMAL & & 0.0133 & 27 & 0 & NORMAL & \\
\hline 0.0027 & 35 & 0 & NORMAL & & 0.0133 & 30 & 0 & NORMAL & \\
\hline 0.0027 & 35 & 0 & NORMAL & & 0.0135 & 27 & 0 & NORMAL & 0.01087 \\
\hline 0.0027 & 35 & 0 & NORMAL & & 0.0135 & 30 & 0 & NORMAL & \\
\hline 0.0027 & 35 & 0 & NORMAL & & 0.0135 & 33 & 0 & NORMAL & \\
\hline 0.0027 & 35 & 0 & NORMAL & & 0.0137 & 24 & 0 & NORMAL & 0.01103 \\
\hline 0.0027 & 35 & 0 & NORMAL & & 0.0137 & 32 & 0 & NORMAL & \\
\hline
\end{tabular}




\begin{tabular}{|c|c|c|c|c|c|c|c|c|}
\hline 0.0027 & 35 & 0 & NORMAL & 0.0137 & 32 & 0 & NORMAL & \\
\hline 0.0027 & 35 & 0 & NORMAL & 0.0139 & 21 & 0 & NORMAL & 0.01119 \\
\hline 0.0027 & 35 & 0 & NORMAL & 0.0141 & 34 & 0 & NORMAL & 0.01135 \\
\hline 0.0027 & 35 & 0 & NORMAL & 0.0143 & 27 & 0 & NORMAL & 0.01151 \\
\hline 0.0027 & 35 & 0 & NORMAL & 0.0143 & 30 & 1 & NORMAL & 0.19587 \\
\hline 0.0027 & 35 & 0 & NORMAL & 0.0143 & 32 & 0 & NORMAL & \\
\hline 0.0027 & 35 & 0 & NORMAL & 0.0145 & 24 & 0 & NORMAL & 0.01167 \\
\hline 0.0027 & 35 & 0 & NORMAL & 0.0145 & 29 & 1 & NORMAL & 0.19861 \\
\hline 0.0027 & 35 & 0 & NORMAL & 0.0145 & 32 & 0 & NORMAL & \\
\hline 0.0027 & 35 & 0 & NORMAL & 0.0149 & 32 & 0 & NORMAL & 0.01199 \\
\hline 0.0027 & 35 & 0 & NORMAL & 0.0154 & 18 & 0 & NORMAL & 0.01240 \\
\hline 0.0027 & 35 & 0 & NORMAL & 0.0154 & 18 & 0 & NORMAL & \\
\hline 0.0027 & 35 & 0 & NORMAL & 0.0154 & 24 & 0 & NORMAL & \\
\hline 0.0027 & 35 & 0 & NORMAL & 0.0154 & 32 & 0 & NORMAL & \\
\hline 0.0027 & 35 & 0 & NORMAL & 0.0158 & 20 & 0 & NORMAL & 0.01272 \\
\hline 0.0027 & 35 & 0 & NORMAL & 0.0159 & 27 & 0 & NORMAL & 0.01280 \\
\hline 0.0027 & 35 & 0 & NORMAL & 0.0159 & 33 & 0 & NORMAL & \\
\hline 0.0027 & 35 & 0 & NORMAL & 0.0159 & 33 & 0 & NORMAL & \\
\hline 0.0027 & 35 & 0 & NORMAL & 0.0159 & 33 & 0 & NORMAL & \\
\hline 0.0027 & 35 & 0 & NORMAL & 0.0161 & 25 & 0 & NORMAL & 0.01296 \\
\hline 0.0027 & 35 & 0 & NORMAL & 0.0161 & 30 & 0 & NORMAL & \\
\hline 0.0027 & 35 & 0 & NORMAL & 0.0164 & 29 & 0 & 21 & 0.01320 \\
\hline 0.0027 & 35 & 0 & NORMAL & 0.0167 & 33 & 0 & NORMAL & 0.01344 \\
\hline 0.0027 & 35 & 0 & NORMAL & 0.0167 & 33 & 0 & NORMAL & \\
\hline 0.0027 & 35 & 0 & NORMAL & 0.0169 & 15 & 1 & NORMAL & 0.01360 \\
\hline 0.0027 & 35 & 0 & NORMAL & 0.0169 & 32 & 0 & NORMAL & \\
\hline 0.0027 & 35 & 0 & NORMAL & 0.0172 & 32 & 0 & NORMAL & 0.01385 \\
\hline 0.0027 & 35 & 0 & NORMAL & 0.0172 & 32 & 0 & NORMAL & \\
\hline 0.0027 & 35 & 0 & NORMAL & 0.0172 & 32 & 0 & NORMAL & \\
\hline 0.0027 & 35 & 0 & NORMAL & 0.0175 & 19 & 0 & NORMAL & 0.01409 \\
\hline 0.0027 & 35 & 0 & NORMAL & 0.0185 & 29 & 0 & NORMAL & 0.01489 \\
\hline 0.0027 & 35 & 0 & NORMAL & 0.0185 & 33 & 0 & NORMAL & \\
\hline 0.0027 & 35 & 0 & NORMAL & 0.0185 & 33 & 0 & NORMAL & \\
\hline 0.0027 & 35 & 0 & NORMAL & 0.0186 & 29 & 0 & NORMAL & 0.01497 \\
\hline 0.0027 & 35 & 0 & NORMAL & 0.0188 & 25 & 0 & NORMAL & 0.01513 \\
\hline 0.0027 & 35 & 0 & NORMAL & 0.0192 & 24 & 0 & NORMAL & 0.01546 \\
\hline 0.0027 & 35 & 0 & NORMAL & 0.0192 & 31 & 0 & NORMAL & \\
\hline 0.0027 & 35 & 0 & NORMAL & 0.02 & 28 & 0 & NORMAL & 0.01610 \\
\hline 0.0027 & 35 & 0 & NORMAL & 0.0204 & 17 & 0 & NORMAL & 0.01642 \\
\hline 0.0027 & 35 & 0 & NORMAL & 0.0204 & 17 & 0 & NORMAL & \\
\hline 0.0027 & 35 & 0 & NORMAL & 0.0204 & 26 & 0 & NORMAL & \\
\hline 0.0027 & 35 & 0 & NORMAL & 0.0204 & 27 & 0 & NORMAL & \\
\hline 0.0027 & 35 & 0 & NORMAL & 0.0204 & 29 & 0 & NORMAL & \\
\hline 0.0027 & 35 & 0 & NORMAL & 0.0204 & 29 & 0 & NORMAL & \\
\hline 0.0027 & 35 & 0 & NORMAL & 0.0204 & 33 & 0 & NORMAL & \\
\hline 0.0027 & 35 & 0 & NORMAL & 0.0213 & 22 & 0 & NORMAL & 0.01715 \\
\hline 0.0027 & 35 & 0 & NORMAL & 0.0213 & 22 & 0 & NORMAL & \\
\hline
\end{tabular}




\begin{tabular}{|c|c|c|c|c|c|c|c|c|c|}
\hline 0.0027 & 35 & 0 & NORMAL & & 0.0213 & 24 & 1 & 18 & 0.29175 \\
\hline 0.0027 & 35 & 0 & NORMAL & & 0.0213 & 27 & 0 & NORMAL & \\
\hline 0.0027 & 35 & 0 & NORMAL & & 0.0213 & 27 & 0 & NORMAL & \\
\hline 0.0027 & 35 & 0 & NORMAL & & 0.0222 & 20 & 0 & NORMAL & 0.01787 \\
\hline 0.0027 & 35 & 0 & NORMAL & & 0.0222 & 21 & 0 & NORMAL & \\
\hline 0.0027 & 35 & 0 & NORMAL & & 0.0222 & 33 & 0 & NORMAL & \\
\hline 0.0027 & 35 & 0 & NORMAL & & 0.0244 & 22 & 0 & NORMAL & 0.01964 \\
\hline 0.0027 & 35 & 0 & NORMAL & & 0.0244 & 23 & 0 & NORMAL & \\
\hline 0.0027 & 35 & 0 & NORMAL & & 0.0244 & 24 & 0 & NORMAL & \\
\hline 0.0027 & 35 & 0 & NORMAL & & 0.0244 & 25 & 0 & NORMAL & \\
\hline 0.0027 & 35 & 0 & NORMAL & & 0.0244 & 31 & 0 & NORMAL & \\
\hline 0.0027 & 35 & 0 & NORMAL & & 0.025 & 24 & 0 & NORMAL & 0.02013 \\
\hline 0.0027 & 35 & 0 & NORMAL & & 0.0263 & 29 & 0 & NORMAL & 0.02117 \\
\hline 0.0027 & 35 & 0 & NORMAL & & 0.027 & 30 & 0 & NORMAL & 0.02174 \\
\hline 0.0027 & 35 & 0 & NORMAL & & 0.0285 & 21 & 0 & NORMAL & 0.02294 \\
\hline 0.0027 & 35 & 0 & NORMAL & & 0.0286 & 21 & 0 & NORMAL & 0.02302 \\
\hline 0.0027 & 35 & 0 & NORMAL & & 0.0286 & 31 & 0 & NORMAL & \\
\hline 0.0027 & 35 & 0 & NORMAL & & 0.0286 & 31 & 0 & NORMAL & \\
\hline 0.0027 & 35 & 0 & NORMAL & & 0.0294 & 25 & 1 & NORMAL & 0.40269 \\
\hline 0.0027 & 35 & 0 & NORMAL & & 0.0303 & 25 & 1 & NORMAL & 0.41502 \\
\hline 0.0027 & 35 & 0 & NORMAL & & 0.0303 & 25 & 0 & NORMAL & 0.02439 \\
\hline 0.0027 & 35 & 0 & NORMAL & & 0.0313 & 29 & 0 & NORMAL & 0.02520 \\
\hline 0.0027 & 35 & 0 & NORMAL & & 0.0313 & 31 & 0 & NORMAL & \\
\hline 0.0027 & 35 & 0 & NORMAL & & 0.0313 & 33 & 0 & NORMAL & \\
\hline 0.0027 & 35 & 0 & NORMAL & & 0.033 & 19 & 0 & NORMAL & 0.02657 \\
\hline 0.0027 & 35 & 0 & NORMAL & & 0.0357 & 30 & 0 & NORMAL & 0.02874 \\
\hline 0.0027 & 35 & 0 & NORMAL & & 0.0357 & 30 & 0 & NORMAL & \\
\hline 0.0027 & 35 & 0 & NORMAL & & 0.0357 & 30 & 0 & NORMAL & \\
\hline 0.0027 & 35 & 0 & NORMAL & & 0.0357 & 31 & 0 & NORMAL & 0.38574 \\
\hline 0.0027 & 35 & 0 & NORMAL & & 0.037 & 27 & 0 & NORMAL & 0.02979 \\
\hline 0.0027 & 35 & 0 & NORMAL & & 0.0385 & 18 & 0 & NORMAL & 0.03099 \\
\hline 0.0027 & 35 & 1 & NORMAL & 0.0369819 & 0.04 & 21 & 1 & NORMAL & 0.54788 \\
\hline 0.0027 & 35 & 0 & NORMAL & & 0.04 & 31 & 0 & NORMAL & 0.03220 \\
\hline 0.0027 & 35 & 0 & NORMAL & & 0.04 & 31 & 0 & NORMAL & \\
\hline 0.0027 & 35 & 0 & NORMAL & & 0.0417 & 30 & 0 & 21 & 0.03357 \\
\hline 0.0027 & 35 & 0 & NORMAL & & 0.0417 & 32 & 1 & 21 & 0.57116 \\
\hline 0.0027 & 35 & 0 & NORMAL & & 0.0476 & 23 & 0 & NORMAL & 0.03832 \\
\hline 0.0027 & 35 & 0 & NORMAL & & 0.05 & 18 & 0 & NORMAL & 0.04025 \\
\hline 0.0027 & 35 & 0 & NORMAL & & 0.05 & 18 & 0 & NORMAL & \\
\hline 0.0027 & 35 & 0 & NORMAL & & 0.05 & 19 & 0 & NORMAL & \\
\hline 0.0027 & 35 & 0 & NORMAL & & 0.05 & 21 & 0 & NORMAL & \\
\hline 0.0027 & 35 & 0 & NORMAL & & 0.05 & 28 & 0 & NORMAL & \\
\hline 0.0027 & 35 & 0 & NORMAL & & 0.05 & 30 & 0 & NORMAL & \\
\hline 0.0027 & 35 & 0 & NORMAL & & 0.05 & 31 & 0 & NORMAL & \\
\hline 0.0027 & 35 & 1 & NORMAL & 0.0369819 & 0.05 & 31 & 0 & NORMAL & \\
\hline 0.0027 & 35 & 1 & NORMAL & 0.0369819 & 0.0527 & 30 & 0 & NORMAL & 0.04242 \\
\hline 0.0027 & 35 & 0 & NORMAL & & 0.0556 & 25 & 0 & NORMAL & 0.04476 \\
\hline
\end{tabular}




\begin{tabular}{|c|c|c|c|c|c|c|c|c|c|}
\hline 0.0027 & 35 & 0 & NORMAL & & 0.0588 & 22 & 0 & NORMAL & 0.04733 \\
\hline 0.0027 & 35 & 0 & NORMAL & & 0.0588 & 33 & 0 & NORMAL & \\
\hline 0.0027 & 35 & 0 & NORMAL & & 0.0833 & 19 & 0 & NORMAL & 0.06706 \\
\hline 0.0027 & 35 & 0 & NORMAL & & 0.0909 & 33 & 0 & NORMAL & 0.07317 \\
\hline 0.0027 & 35 & 0 & NORMAL & & 0.0909 & 33 & 0 & NORMAL & \\
\hline 0.0027 & 35 & 0 & NORMAL & & 0.1 & 20 & 0 & NORMAL & 0.08050 \\
\hline 0.0027 & 35 & 0 & NORMAL & & 0.1 & 22 & 0 & NORMAL & \\
\hline 0.0027 & 35 & 0 & NORMAL & & 0.125 & 26 & 0 & NORMAL & 0.10063 \\
\hline 0.0027 & 35 & 0 & NORMAL & & 0.125 & 29 & 0 & NORMAL & \\
\hline 0.0027 & 35 & 0 & NORMAL & & 0.1667 & 33 & 0 & NORMAL & 0.13419 \\
\hline 0.0027 & 35 & 0 & NORMAL & & 0.1667 & 33 & 0 & NORMAL & \\
\hline 0.0025 & 35 & 0 & NORMAL & 0.0020125 & 0.3333 & 25 & 0 & NORMAL & 0.26831 \\
\hline 0.0021 & 40 & 1 & 21 & 0.0287637 & 0.5 & 33 & 0 & NORMAL & 0.40250 \\
\hline
\end{tabular}

